\title{
Aesthetics, Accessibility and User-centered design: An analysis of the University of Otago Library Special Collections online exhibitions 2002-2013
}

\author{
By \\ Monique Aimee Black
}

Submitted to the School of Information Management,

Victoria University of Wellington

In partial fulfilment of the requirements for the degree of

Master of Information Studies

February 2014 


\begin{abstract}
Research Problem: This study analyses 42 online exhibitions which are currently available on the University of Otago Library Special Collections web page. The research integrates aesthetics, accessibility and user-centered design and focusses on each exhibitions functionality and appeal within these parameters.
\end{abstract}

Methodology: The intention of this research is to compare and contrast 42 online exhibitions up until November 2013, with additional in-depth analysis of ten selected online exhibitions. Tools used were an LG wide-screen monitor and PC, and exhibitions were accessed via the Mozilla Firefox web browser 24.2.0.

Results: Three clear issues with the exhibitions design were identified: 1) in the majority of exhibitions, the size of the type used was smaller than recommended accessibility guidelines, and fluctuated over time; 2) labelling rather than numbering cabinets in an index created improved usability; 3 ) overall aesthetics and functionality within the exhibitions improved over time, reflecting available technology.

Implications: The 42 online exhibitions analysed provide insight into how available technology has improved the aesthetic appearance of the exhibitions and their functionality since 2002. The latter exhibitions contain far more images, varied and appealing page design, and an unobtrusive provision of further information on the cabinet artefacts. Usability and accessibility could be enhanced by consistent 12 point type within the main body and cabinets of the exhibitions, in addition to consistent labelling of cabinets which provides the patron a better understanding of the whole exhibitions theme, and the cabinets, wall and vitrines without too much 'clicking'. Areas for future research into accessibility and patron inclusivity in online exhibitions for libraries are highlighted.

Keywords: online exhibitions, user-centered design, accessibility, aesthetics 


\section{Table of Contents}

Abstract 2

Acknowledgements 4

Introduction $\quad 5$

$\begin{array}{lr}\text { Background of study } & 6\end{array}$

$\begin{array}{ll}\text { Selection and Objectives of Study } & 7\end{array}$

$\begin{array}{ll}\text { Research Questions } & 8\end{array}$

Inclusions and delimitations of this research 9

$\begin{array}{ll}\text { Literature Review } & 11\end{array}$

Online Exhibitions- the format $\quad 11$

Aesthetics, accessibility and User-Centered Design 12

European studies in Online Exhibitions and Library Users $\quad 15$

Digital cultural heritage and User-Centered design 18

User-Centered design and accessibility: within library websites, and beyond 20

Methodology 21

$\begin{array}{ll}\text { Theoretical framework } & 22\end{array}$

Metrics $\quad 23$

Research Design $\quad 24$

Discussion and Analysis $\quad 24$

Findings $\quad 28$

Cabinet usability and font size $\quad 30$

Conclusions $\quad 32$

Recommendations for future research $\quad 32$

References 36

Bibliography $\quad 38$

Appendix I

Appendix II

Appendix III

Appendix IV 


\section{Acknowledgements}

Many thanks to my wonderful supervisor, Shannon Wellington- your guidance, feedback and support were incredibly helpful.

I would like to thank the University of Otago for its generous funding of my studies and my colleagues for their support.

To Dr. Donald Kerr, who created and collaborated on these myriad online exhibitionsthank you for your insight and wisdom regarding these unique collections.

Thank you to my brilliant family and friends in New Zealand and around the world.

I would particularly like to thank my four beautiful, clever and kind sisters: Katie, Sophie, Ellah and Chloe. I am very lucky to have best friends like you.

Endless thanks to my loving, insightful and supportive parents David and Nicolette- we five are blessed to have you as parents.

To my grandparents Betty Black and the late Bernard Black, for always showing an interest in and supporting me and my seemingly never-ending studies. (All finished!)

To my Grandmother, Alfreda Ridley, who is the best example of how to live well and treat others with kindness, love and good humour you could encounter.

To Lily and Rosa, the two cutest dogs ('piggies') anyone could hope to cohabitate with. Time for lots of cuddles and treats!

To Hamish, for everything. I love you always.

This research project is for my Grandfather, William 'Bill' Ridley who passed in December 2011. He may not have enjoyed the topic (not enough deer-stalking anecdotes), but he would have been proud I completed this qualification at last.

Monique Black

February 2014 


\section{Introduction}

The University of Otago Library Special Collections contains over 12,800 rare monographs, manuscripts and artworks, maintained by the Special Collections librarian with help from members of reference services, information systems and reprographics. Each year, this archive material is used as a basis for four semi-concurrent live and online exhibitions. Each live exhibition runs for four months, and an online version is added to the library database during this period. I intend to review the University of Otago Library Special Collection online exhibitions between 2002 and 2013 and analyse their accessibility, aesthetic appeal and use of user-centered design. As of July 2013, the number of online exhibitions on the library website totalled 42 . This provides an ample pool of sample exhibitions for study and comparison. In the eleven years since the online exhibitions were first created, user needs have also evolved- I predict this to be reflected in the tone, design and accessibility of the exhibitions.

My study will primarily focus on aesthetics, which while integrating all three aspects (aesthetics, accessibility and user-centered design) will be mainly concentrated on functionality and the 'look' and 'feel' of the exhibition. Aesthetic exhibitions that also serve a functional purpose strike a balance between formalist and analyst styles, providing plenty for the patron to view in terms of images, and providing interesting and relevant information simultaneously. 


\section{Background of Study}

Special Collections purpose is to:

'-Strengthen, support and encourage the University's current research and teaching

-To stimulate academics to identify new research and teaching

-To develop coherent collections which build on existing strength's

-To provide appropriate conditions to preserve the resources in the collection

-To provide access to the wider community

-To preserve the materials within for future generations'

(Special Collections Collection Development Policy, 2013)

By making these artefacts available digitally, Special Collections can provide access to the wider- global- community, and integrate the research of alumni and local and national artists and authors. The Special Collections Overview further states that:

'Users include staff and students of the University, individuals from other tertiary organisations (Otago Polytechnic), and independent scholars, local and international. High departmental users within the University include the English, Art history, Applied Sciences (Design), History, Anthropology, Classics, and Religious and Theology Departments. The collection is regarded as "the jewel in the crown" and as such it attracts visitors. There are individuals who want to experience the touch, sight and smell of an old book; others merely view the quarterly exhibitions.' The online exhibitions provide an avenue for a global audience to access these 'jewels' of the library. 


\section{Selection and Objectives of Research}

My interest in this subject was piqued by my initial discovery of the Special Collections exhibitions on the University of Otago Library site. At first I had difficulty in finding the exhibitions themselves due to a lack of promotion on the library website. What I found when I got there, however, was a rich trove of digital artefacts- rare paintings and prints, and works by alumni, local, national and international artists and authors. The vast amount of information and images contained in each of the exhibitions, and the obvious time taken in crafting the live and online iterations caused me to wonder at why they weren't promoted more within the university and globally. In casual conversation with many library colleagues and students, on mentioning my research topic, most noted they had no idea Special Collections had perpetual online exhibitions, let alone 44 stretching back to 2002.

I have used examples from both heritage studies and web design, particularly research that focusses on user-centered design and accessibility. At the time of this study, there was a gap in this area of research specific to online exhibitions within heritage institutions. 


\section{Research questions}

1. What aspects of the online exhibitions design has changed since 2002 ?

What key features have remained the same?

Sub questions:

-What motivated these changes?

-Purely aesthetic?

-To suit the exhibition theme?

-Based on trends/ influenced by other exhibitions?

2. If examples of 2012 Otago Exhibitions are 'better' than previous ones, is this just reflective of available technology?

3. What are the benefits of maintaining open online exhibitions?

Sub questions:

-To the library/Special Collections?

-To the user- maintaining and cultivating a global audience? 


\section{Inclusions and delimitations of this research}

\begin{tabular}{|l|l|}
\hline In Scope & Out of Scope \\
\hline Visual appearance of each online & Technical website design criteria \\
exhibition, including: layout, font, colour, & \\
\hline $\begin{array}{l}\text { Visual appearance and description of } \\
\text { artefacts for benefit of patron }\end{array}$ & In-depth analysis of adherence to \\
\hline
\end{tabular}

In assessing all exhibitions, there are numerous reasons why an exhibition may have broken links or its design has not been tested for accessibility before being made available online. However, speculation over the origin of such issues is beyond the scope of this research.

I have surveyed all 42 exhibitions, and my main criteria for assessment are based on Krug's 'Don't Make Me Think-Accessibility and You (Ch.12, p.173-181.) In addition to this I have also evaluated IBM's web accessibility policies and WCAG guidelines detailed on accessify.com and Penn State's 'AccessAbility' low vision and font size assessments. Web Content Accessibility Guidelines (WCAG):

'....are a set of guidelines for making content accessible, primarily for disabled users. The current version, 2.0, is also an ISO standard, (ISO/IEC 40500:2012.)' (AccessAbility, 2014) 
I have not utilised online accessibility assessors on any of the exhibitions, for several reasons. One is that many checks and recommendations require knowledge of web coding, which is beyond the scope of this project. Second, as Krug states, the assessors often come up with vague statements indicating the web page may have some errors- but that they may not be problems at all. The third- and most important reason- is that the concept of accessibility in online exhibitions is vast, and requires a large amount of manual testing and technical knowledge. I felt it was better to focus on three key areas as part of this research than attempt to cover all aspects within limited scope.

In addition to this, I have assessed colour use primarily in an aesthetic fashion. If the use of colour helps the overall appearance of an exhibition, it will be noted on. In extreme examples (for example, when the whole exhibition background is green, red, black, or utilises vibrant wallpaper) a suggestion for referring to WCAG guidelines may be recommended. In short, I am not addressing the web design code which forms the exhibition- I am assessing each one from the perspective of a patron who just wishes to access materials which are presented in a user friendly, accessible, and aesthetically pleasing fashion. By identifying and addressing usability issues accessibility will be heightened.

WCAG guideline 1.4.4 states that 'except for captions and images of text, text can be resized without assistive technology up to 200 percent without loss of content or functionality' and that a minimum of 9 point for footer information and a recommended size of no smaller than 12-14 point for body text is required on all web pages. (AccessAbility, 2014.) 


\section{Literature Review}

\section{Online Exhibitions- the format}

Kalfatovic (2001) provides an historical overview of online exhibitions, and advice on selecting a concept for and maintaining an online exhibition.

This article is informed by the author's investigations and experience in creating welldesigned online exhibitions, and includes examples from ten exhibitions from United States institutions.

Kalfatovic notes the benefits of creating and maintaining online exhibitions. They are cost effective, easy to maintain and allow the library, archive or museum to gain a global audience and promote the institution. This is echoed by Liew's (2006) discussion of social inclusion as a motivating factor for creating online exhibitions. Online exhibitions also provide an opportunity to display fragile or rare materials, which otherwise would remain hidden in a library's archives. Kalfatovic (2002) also notes the importance of selections and themes when creating an online exhibition. He divides the online exhibition into five types: the aesthetic, emotive, evocative, didactic and entertaining. This provides a framework that may be adapted for individual analysis of Otago exhibitions.

This advice on how to best create a good online exhibition can be used as a comparative list of concepts used in the 42 University of Otago Special Collections exhibitions. As the idea behind any exhibition is the most important feature, the suggestions of themes, treasures and 'odd and unusual' ideas can be seen throughout the Otago exhibitions.

Vandi (2011) discusses the cross-promotion of library resources, museum exhibitions and 
virtual collections at the Bibliotheque des Sciences et de l'Industrie- part of Frances largest science library. The author discusses the integration of mobile technology to attract new users, connecting the live and virtual exhibitions. Similar mobile technology is used at the American Museum of Natural History in New York, where patron can use mobiles in the live exhibits to gain further information about artefacts. The cross-promotion via live and virtual exhibitions is an area that has already been explored by the University of Otago to enhance user experience.

\section{Aesthetics, accessibility and User Centred Design}

Based on Thomas L. Friedman's discussion of the relationship between networks and globalization, the concept of the 'World is Flat' is here discussed in relation to the evolution of museums and libraries into 'virtual destinations'. Tonta discusses the relationship between the physical and the virtual and how cultural heritage resource can be digitized (Tonta, 2008.)

Tonta reviews current research on digitization and the evolution of museums and libraries. Friedman's book 'The World is Flat' provides the inspiration for this research, which states that through the interconnectivity by virtue of the internet, users and cultural archives can collaborate and compete globally.

By drawing comparisons with Amazon and Google, libraries are now competing with and connected via instantaneous information sources- the internet is one of ten 'flatteners' described by Freidman (2005). As patrons come to expect a high level of access, cultural 
institutions have followed suit by providing both digitized collections and curated online exhibitions.

Tonta's discussion of Europe's digitization of cultural heritage provides a point of comparison for my own research. Europe has a number of archival digitization projects in order to preserve items which have 'fundamental value for Europe's present and future'. The Otago Library exhibitions comprise both local and European artefacts and themes. While the preservation itself serves the purpose of saving the information for future generations, the accessibility and aesthetics of the exhibition is imperative to assess. Tonta's assessment contrasts with that of Milekic (2007), who questions the value to the patron of digitised collections which lack engagement and 'knowledge transfer' when compared to the print version. The challenges are twofold for online exhibition designers: they must 'support user interactions that contribute to information transfer and retention, and make the quality of virtually presented information meet or exceed a real life experience'.

Milekic provides the example of viewing a thumbnail of a great work of art on a computer screen- how can it 'convey the essence' of a masterpiece by Renoir or Picasso? The author suggests methods to create a more tangible experience via 'virtual exploratory/learning tools'. The digital 'magnifying glass' utilizes high resolution scans of materials and a simple digital 'magnifying glass'. By placing the cursor over the image, patrons can take a closer look at artefacts which most likely cannot be handled by patrons, protecting the material and providing access to more information that a standard 'live' exhibition could. This tool is in use in the 2004 University of Otago online exhibition 'Glimpses of London's Past', and 
several others to be analysed, clearly indicating that user centred design is integral to engaging patrons with digitized material.

Liew (2006) provides an overview of the technological advances in the creation of online exhibitions for cultural institutions, highlighting global developments in online exhibitions, and by comparing institutions approaches, objectives and exhibition content indicates areas where further research is required.

Research was undertaken via personal investigation by the author conducted between February and June 2004 of a selection of 15 online exhibitions. The study gives an overview of exhibitions from around the world, primarily in western developed nations including Australia and New Zealand.

Liew highlights the value of online exhibitions as a source of social inclusion. The promotion of online exhibitions allows a wider audience to access materials at any time. This is broadened to include search and retrieval features on all 15 sites, noting that the browsing features on the various sites are different, however each provides a basic search function (Liew, 2006). Major findings indicated that future exhibitions will utilise multimedia browsing, and should explore multi- or bilingual search options.

This method of presenting information could be used as a template for both my analysis of the 42 Otago exhibitions, and comparison with European exhibitions. The findings also provide an excellent overview of institutions exhibitions in Australasia, North America and Europe.

Liew's study provides the only comprehensive analysis of global online exhibitions both by a New Zealand academic and including New Zealand examples in addition to international 
examples. As my comparative study will integrate both local and global components this study is both comprehensive and useful as an analysis of what aesthetic and accessibility features were broadly used in 2004 compared to current exhibitions.

\section{European studies in Online Exhibitions and Library Users}

Stigter (2009) analysed the role of cultural institutions in virtual communities. The European library is a digital library launched in 2005 , and provides integrated access to national library resources from across Europe. It provides access to books, journals, maps, films, photos and music. This collaborative archive provides users access to a 'massive amount of content from a great number of institutions from across Europe' (Stigter, 2009). The location of the physical artefact is no impediment to digital access for patrons. This collaborative institution allows a global audience to view priceless historical artefacts. As an access point, it also promotes 'a sense of European identity'. Comparisons can be drawn with Otago's online exhibitions. The works of John Buckland Wright, a Dunedin artist, was in October 2012 the most popular online exhibition and attracts a global audience, conveying a sense of 'New Zealand identity' to patrons.

Ongena et al (2012) completed a case study analysing the business to consumer market for digital audio-visual archiving services. The research adopts a STOF framework (service, technological, organizational and financial) which is appropriate for market analysis, but not for content analysis which I will adopt. Ongena concludes that design issues impact the 
audio-visual archive. Focused on preservation of materials, the archives service gives little attention to the design of the site itself. By focusing on presentation, the archive could attract a wider audience. These key design issues are also applicable to analysis of Otago's special collections online exhibitions.

Lester (2006) discusses the implications of attempting to replicate the physical exhibition into an online format, and whether this is a natural progression for exhibitions display- as an extension, rather than a replacement for the physical experience. By considering traditional museum display techniques, in addition to the best method of displaying archival documents in an online format, Lester seeks to discuss the possibilities of the virtual format.

The author bases his analysis on both an overview of museum sector studies, and archival exhibitions. This was completed via a questionnaire sent by the author in July 2003 to the creators of 35 physical and 12 online exhibitions.

In order to cater to a broad audience, the author recommends utilising website feedback, online questionnaires and various studies to ensure that the exhibition does not become a static, one directional conversation directed at the patron. Lester also notes that the best way to make an online exhibition user-friendly- other than design function- is to ensure a balance between formalist and analyst methods on display.

Lester's discussion of the balance needed when creating an online exhibition provides a basis for analysing the University of Otago online exhibitions. The discussion of formalist versus analyst methodology could be a valuable comparative study of the exhibitions- and whether Lester's recommended balance of the two has been achieved. 
This analysis of the online exhibition as a possible successor to the physical, in addition to examples of interactive exhibition approaches from Europe (for example, the British Libraries 'Turning the Pages' exhibit 2003) could form a basis for comparison between European and University of Otago methodology.

The National Information Standards Organization (NISO) has produced guidelines for building 'good digital collections' (NISO Framework Working Group, 2007.) Of the nine principles for maintaining a good digital collection, all are applicable to online exhibitions. This content analysis will focus on adapting these metrics to the online exhibition, which is detailed in Methodology.

Muller (2002) discusses specific advantages and perceived threats of the online exhibitions, and the web itself. Written in 2002, this article provides an insight into how the interconnected nature of the web and museum exhibitions can align to meet the needs of the patron. Notable points made are how one must consider the disabled online visitor. Muller discussed the crossover from physical to virtual exhibitions with colleagues at the Salzburg Seminar (2001) and used these interviews, in addition to a personal survey of global online exhibitions.

Muller outlines the possible threat of devaluation of the museum experience and the possible decrease in patron attendance at physical exhibitions, and the need to modify expectations of the exhibition to two-dimensionality. Similar to interactive physical museum exhibits, an extra layer of meaning can be added via hypertextuality of the online exhibition.

Special Collections (University of Otago Library) first began creating online exhibitions in 
2002. This article provides a background for some of the concerns and possibilities of this new medium at the time, and compliments the other readings positive view of the broad scope for interactivity and global accessibility.

The most pertinent aspect of this article was the discussion of hypertextuality, particularly the addition of audio content to exhibitions, in addition to current descriptions of artefacts. This would greatly benefit the visually impaired and could also provide a further means of accessing artefacts.

Lester's discussion of formalist and analyst exhibitions provides a framework for comparing the Special Collections exhibitions and analysing the difference in accessibility between 2002 and 2012. Tonta's discussion of the library as a virtual destination- an inescapable result of global interconnectivity- confirms the need for further study of this medium. This is also useful in addition to Muller and Kalfatovic's overview of what is essential in assessing a successful exhibition- a strong core concept which is complimented by user friendly aesthetics. Liew's method of comparison between local and international exhibitions will also inform my own methodology- in utilising metrics on accessibility features.

\section{Digital Cultural Heritage and user-centered design}

In 'Beyond the Cult of the Replicant', Cameron references Witcomb (2003):

'the basis of museological integrity and mission is founded on the formation of cultural capital and the selection of and attribution of value that upholds and sustains the meaningful deployment and circulation of collections as material evidence, original, 
authentic, as knowledge, as representative of the passage of time, and as signs of power and privilege' (Witcomb, 2003)

Here, Witcomb expresses the $19^{\text {th }}$ century perception of the museum or heritage space as a source of power due to its possession of original material evidence. A real place, filled with objects that convey truth due to their materiality- they are there, one can see them and the space and its contents are thus rendered powerful and truthful. Russo \& Watkins (2005) compared the post-museum experience, such as the online exhibition, to that of the modernist heritage space. In the modernist museum of the $19^{\text {th }}$ and $20^{\text {th }}$ centuries, the communication of information about artefacts 'focused around minimal labelling while the placement of collections within an architectural space provided a permanent display of the power/knowledge of the museum.' How can we then conceive of the online exhibition? By its very nature, it can only be a copy, a 'replicant', and never an original. But does power need to be intertwined with perception? An objects gravitas is not dependent on it being seen in its original physical state. The artefacts displayed at the Special Collections live exhibitions are enhanced via digitization for the patron, and the original is thus protected and preserved. With magnifying tools, high resolution scans, and constant access for any patron, the online exhibition adds a further level of broad access to a global audience. Instead of being about power and privilege- which $19^{\text {th }}$ century museums certainly were, limiting who and when patrons could enter- the online exhibition levels the field. Russo \& Watkins further note that in the post museum environment, the 'discourse of power and knowledge have been displaced by audience interaction and 'meaning making' (All are welcome, at any time- and the appropriate use of user-centered design and accessibility 
means that the format of an exhibition has the power to open up to a more diverse audience. Cameron echoes this, stating that as 'reproductive technologies improved...a more acute connection could be made between the medium and the creative intention of the maker' (p.55)

By viewing a copy of a text in an online exhibition, the patron can also connect the object with its context and provenance. One cannot magnify or get more information from the small print of an explanatory statement alongside a physical object; one can also seldom get close enough to such precious artefacts to 'examine' them close up. Through the digital medium, the patron can easily do all of these things, which facilitates an 'acute connection', despite it being a copy.

\section{User centered design and accessibility within library websites and beyond}

Raward (2002) notes the challenge in designing a library website that 'that has reliable content and a user interface that is intuitive to those who use it'. (iii, Raward, 2002) This relates directly to the creation of accessible, user centered and aesthetically appealing online exhibitions.

In their discussion of user-centered design in knowledge-creating contexts- such as libraries and museums- Pang and Schauder (2007) mention the shift from techno-centric approaches to design to user-centered design, which 'focuses on human needs' (p.207). The importance of the focus on the user's needs, whether due to accessibility issues or not, are further highlighted in mention of the 'UN Universal Declaration of Human rights...which 
assert the right of every individual to freedom of communication in any medium'.

Shyam Sundar et. al ( 2013) also note also how simplification of design and usability improves user engagement with a web page.

Mellone and Williams (2009) noted in their assessment of the library web site redesign at the Queens College Library (QCL) in New York that in 2007, the website was 'hindering the library's ability to provide information and services effectively to its users', including usability and visibility. Visibility was inhibited by the original web page format of $800 \times 600$ pixels, which had become outdated rather quickly. This is mirrored in the design of the initial five Special Collections exhibitions, which in 2002 and 2003 would have been appropriate resolutions for the screens of the time, but are now outdated and take up only a quarter of the wide screen now in common use. On the QCL website, usability was limited due to tight spacing of images and font on the page. This, combined with a small web page with small font reflects the same accessibility and user-centered design issues noted in some of the Special Collections Online Exhibitions assessed.

\section{Methodology}

I will use the Otago Special Collections Online Exhibition repository as a case study to analyse the evolution and advances in online exhibitions since 2002. I intend to review what technology is utilised and what is not, comparing past exhibitions to current ones and reviewing what formats have been abandoned and what has been improved in terms of usercentered design. In reviewing this, I will be able to determine if the exhibitions individually 
reflect the evolution of digitization, global or local trends. Additional information will be gained via a literature review. excellent Liew (2005) notes that in reviewing the effectiveness of online exhibitions, 'a wide range of metrics and methodologies for evaluation' will be required as technology progresses and online exhibitions and user interactivity increase.

Since Liew's paper was published, there have been no comprehensive case studies that I could locate of online exhibitions in New Zealand libraries. During this time, the University of Otago has continued to add two to four online exhibitions per year reflecting live exhibitions. The comprehensive exhibitions database provides an opportunity to review the effectiveness and purpose for adopting select exhibition features since 2002. The number and temporal span of the exhibitions also provides an ideal way of noting how select recent exhibitions have evolved since 2002, which technologies have been abandoned, and how

functionality and aesthetics have been modified and improved. Waloszek (2003) refers to the various aspects of User Interface Design - science, art and craft. My study will primarily focus on aesthetics, which while integrating all three aspects will be mainly centred on functionality and the 'look' and 'feel' of the exhibition.

\section{Theoretical Framework}

In selecting appropriate metrics to assess Special Collections online exhibitions there is a need to integrate metrics drawn from both the fields of digital heritage and library studies. In several metrics examples, the parameters are too broad for an exhibition, and include a large digital collection which is more repository than exhibitive- this is evident in 'A Framework of Guidance for Building Good Digital Collections' good although reference 
properly. The University of Otago Special Collections integrates print works, still images and physical artefacts- all of which need different treatment in digitization and patron accessibility. The metrics that will be utilized to analyse the research population are drawn from authoritative voices in the field of online exhibition and digital collection analysis, and have been adapted to fit the scope of exhibitions available from the University of Otago. Best practice standards have also been assessed- the key criteria being how these metrics can benefit Special Collections when planning future exhibitions.

\section{Metrics}

Metrics for content analysis are based on 'A Framework of Guidance for Building Good Digital Collections', and integrate concepts from Lester, Kalfatovic, Liew and Milekic.

1. Has a balance of formalist and analyst methodology been achieved? (Lester:2006)

2. Does the exhibition support patron interactions that contribute to information transfer and retention, and make the quality of virtually presented information meet or exceed a real life experience? (Milekic:2007)

3. How can the exhibition be assessed in terms of Kalfatovic's five types of online exhibition: is it aesthetic, emotive, evocative, didactic or entertaining, or a composite of several of these definitions?

4. Is the exhibition maintained and actively managed to ensure all links are accessible to patrons?

5. Is the design such that it is easy to navigate and does not contain too much or too sparse a range of artefacts per page? 
6. Is the exhibition accessible to persons with disabilities, including adaptive technology?

7. Does the exhibition provide usage data and other data to assess standardization and usefulness?

8. How does the exhibition reflect local and national culture, and the purpose of the special collections?

\section{Research design}

The format of my research project is a content analysis. I have studied in detail the design, aesthetics and functionality of ten online exhibitions from the University of Otago Special Collections for trends and points of difference. The selected exhibitions span the years 2002 until 2013, in addition to a more brief comparative analysis of all 42 exhibitions. This will allow me to assess the level of thematic difference and variations in functionality, accessibility and aesthetics.

\section{Discussion and analysis}

Both formalist and analyst methodologies can be too reductive when applied to objects within an exhibition. The formalist method displays the object, identifies it succinctly, but does not explain the context or meaning behind it. By providing too little information, whether provenance or historical details, the patron my miss an opportunity to broaden their knowledge or understand the object in context. In contrast, the analyst method can saturate the exhibition with too much information- the objects on display losing context 
within myriad meanings and ideas. In the analyst approach, the objects of the exhibition are road-mark's to convey an exhibitions theme, and may be robbed of their individual impact.

I have collected data by analysing each of the 42 separate University of Otago Library online exhibitions on accessibility and design, and completing in-depth analysis of ten selected exhibitions spanning the years 2002-2013. These exhibitions were analysed based on the following factors:

1. Differentiation. For example, the first five online exhibitions are of near identical design and accessibility. Thus, as a representative sample of the early days of digitizing Special Collections, I have assessed the very first of these, Portrait of a Gentleman Scholar: Celebrating the life and legacy of Esmond de Beer (2002.) Similarly, the design and accessibility of Pulp Fiction, Ray Guns and Rocket Ships and In Search of Scotland follow a similar format; therefore, I have selected 'Pulp Fiction' as a representative example. In addition to this, I also aimed to select a balance of local and international themes, a contrast between modernist and classical subject matter, and a balance of exhibitions which focus on an historical period (A Quick Stab at the $18^{\text {th }}$ Century) and ones that focus on a private collection over time (All Aboard! The Ernie Webber Railway Collection)

2. Comparison. The ten exhibitions are markedly different in design and accessibility, in addition to demonstrating, on the whole, a clear evolution from some consideration of the user to a clearly user- centred design focus. In Don't make me think, Revisited Steve Krug notes that user- centred web design can be simply defined using the following rules, which I have amended for the purposes of assessing an online 
exhibition, as opposed to a web site:

- Know the main things people want to do [while browsing the exhibition] and make them obvious and easy. This is mitigated by making the online cabinets labelled by subject rather than numerically, and ensuring the index of cabinets is visible on each page in the same place.

-Put in effort- this is clearly reflected in clarity of wording, and uncluttered pages which are neither too wordy nor too sparse. I have selected the first two Rare Delights exhibitions as the former achieves this goal more closely than the latter.

-Save the patron steps whenever possible- An example of this is minimizing 'clicks'- instead of using a thumbnail image which , if the patron wants to enlarge it, opens on a new page, allow the user to enlarge the image by using a 'magnifying glass' cursor (see: Glimpses of London's Past, 2004). Also, a one click enlargement of the image which appears in the centre of the screen, and which can be closed by one click while remaining on the page. This minimises effort on behalf of the patron, making navigation easier, and also minimizing the amount of space required to load the page (by using full images on the main page itself.)

-make it easy to recover from errors: If the patron navigates away from the main page, make an anchor link, plus 'previous' and 'next' buttons clearly visible. If the page is long format (requiring vertical scrolling to view all cabinets and vitrines) provide a 'quick scroll' arrow which will allow the patron to 'return home' to the top of the page whenever required.

-Don't make me think: This is Krug's mantra as a website usability consultant. If a pages layout has font that is too small, is aligned in a fashion which makes it difficult 
to navigate, is not aesthetically pleasing or requires too many clicks to roam between cabinets and artefacts, the patron may be frustrated or disheartened.

There is a summarised version of the analysis of the 42 exhibitions in table format, including a page table for each of the ten in-depth analysed exhibitions (see appendices II and III.)

This project required comparative analysis. For the initial analysis, I opened each exhibition as a tab in groups of 10 , then assessed first impression design features such as use of colour, size of font, use of images and clarity of navigation by opening 3-4 'cabinets' per exhibition. I also noted when and if an index of cabinets was listed, if it was by title or numerical, if headings were used, and if the introduction assumed prior knowledge by the patron. I used an amended version of Krug's usability criteria for my broad analysis of all 42 exhibitions.

When assessing the ten selected exhibitions, I gave equal weight to each of the 8 metrics for analysis as defined in my proposal. After this, I compared and contrasted my findings in order to create a clearer picture of the evolution of the exhibitions between 2002 and 2013. If I note that font size is 'too small', that means it is less than the recommended $12-14 \mathrm{pt}$ for body text. All main headings for exhibitions were of an appropriately readable size according to WCAG guidelines.

The ten Exhibitions analysed: 


\begin{tabular}{|c|}
\hline $\begin{array}{l}\text { Portrait of a gentleman scholar: } \\
\text { celebrating the life and legacy of } \\
\text { Esmond de Beer }\end{array}$ \\
\hline $\begin{array}{l}\text { Rare Delights: recent additions to } \\
\text { Special Collections }\end{array}$ \\
\hline $\begin{array}{l}\text { He tirohanga ki muri } \sim \text { A view of the } \\
\text { past }\end{array}$ \\
\hline Glimpses of London's Past \\
\hline Walt Whitman's Leaves of Grass \\
\hline A Quick Stab at the Eighteenth Century \\
\hline $\begin{array}{l}\text { Rare Delights II: Recent Additions to } \\
\text { Special Collections }\end{array}$ \\
\hline $\begin{array}{l}\text { ALL ABOARD! The Ernie Webber } \\
\text { Railway Collection }\end{array}$ \\
\hline Pulp Fiction \\
\hline $\begin{array}{l}\text { From Pigskin to Paper: The Art and } \\
\text { Craft of Bookbinding }\end{array}$ \\
\hline
\end{tabular}

\section{Findings}

Overall the key features that remained the same throughout the exhibitions was both a high level of didactic and aesthetic design, tempered by font sizes that were frequently smaller than recommended for accessibility purposes. Save the first five exhibitions with utilise a similar design, the format of each of the 42 has varied widely, indicating a level of innovation, technological advance and experimentation in how artefacts are presented. Enumeration and titles for cabinets, walls and vitrines displayed online also fluctuate. The use of images, particularly high resolution, enlargeable and thumbnails in place of cabinets have balanced the majority of the latter exhibitions formalist and analyst, where previous 
iterations had tended toward the overly analyst.

From analysis, the motivation for these changes appear to be in step with the technology available- functional yet aesthetically appealing exhibitions have been in the majority for the last three years, compared to previous examples. While the latter exhibitions are certainly 'better' than earlier attempts, the persistent use of font below 12 point inhibits the effect for differently abled users.

The library and specifically Special Collections benefit from the expanding the repository of online exhibitions available to browse each year. This could be increased via analysis of online patron numbers, as a broader audience via promotion could increase both patron numbers to the physical exhibition, and attract potential academic interest. To the user of these exhibitions, there is a wealth of information and images, and on the whole well balanced design that integrates function and aesthetics. To increase audience size and to benefit users further, a review of all current online exhibitions for accessibility and usability would permit reflection on what works and revision of aspect which no longer function as they ought. This applies particularly to exhibitions created between 2002 and 2007, which had a high volume of broken links.

\section{Cabinet Usability}




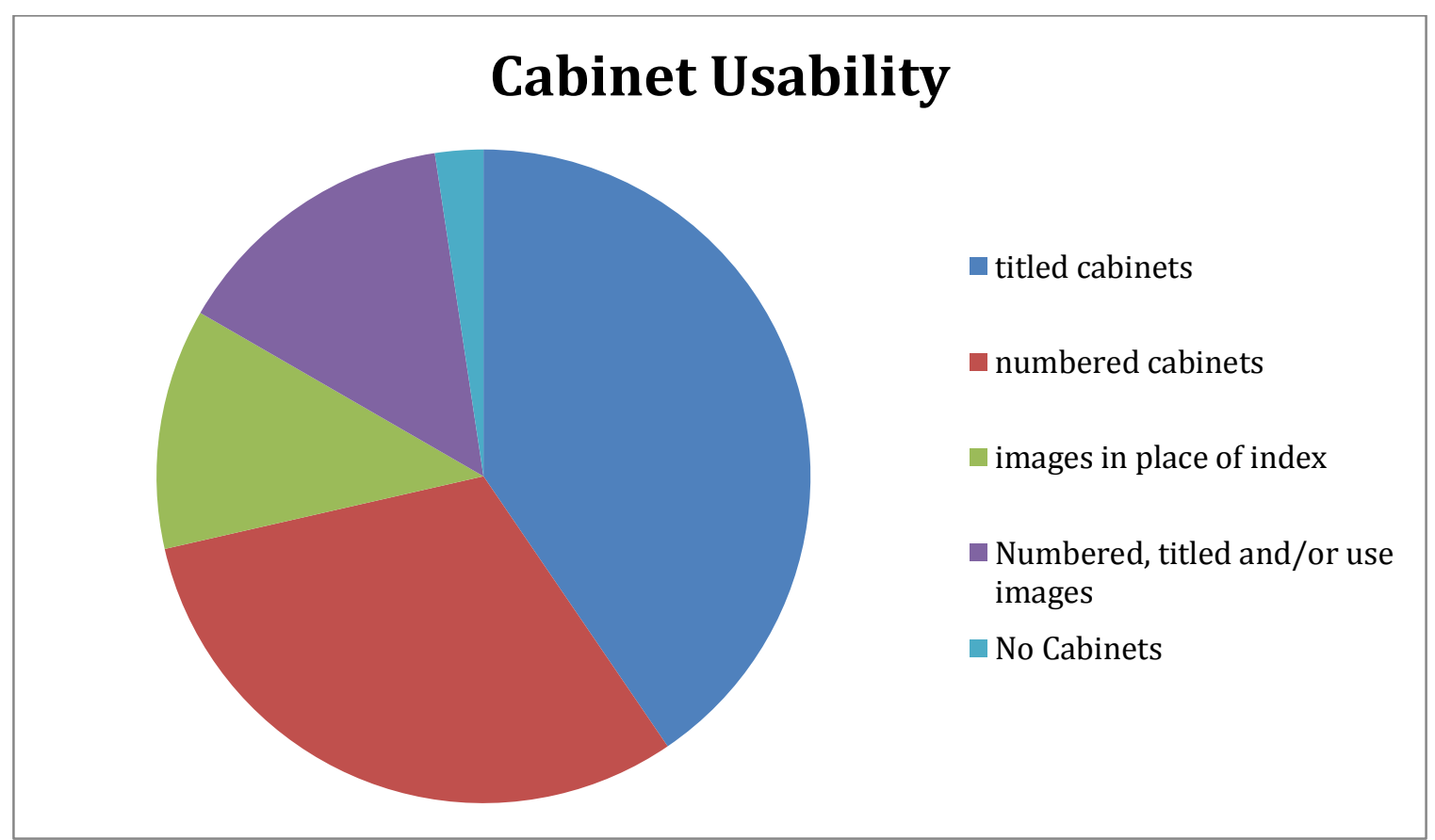

Number of exhibitions with numbered cabinets: 13

Number of Exhibitions with titled cabinets: 17

Number of exhibitions with cabinets that are numbered, titled and/or including thumbnail images: 6

Number of exhibitions that use images instead of titles/numbers: 5

Number of exhibitions that do not utilise any of the above: 1 


\section{Accessibility- body font size}

Note- where the body font size ranges between two sizes, I have selected the one most used as representative of the whole exhibition.

\section{Font size of body text within exhibitions}

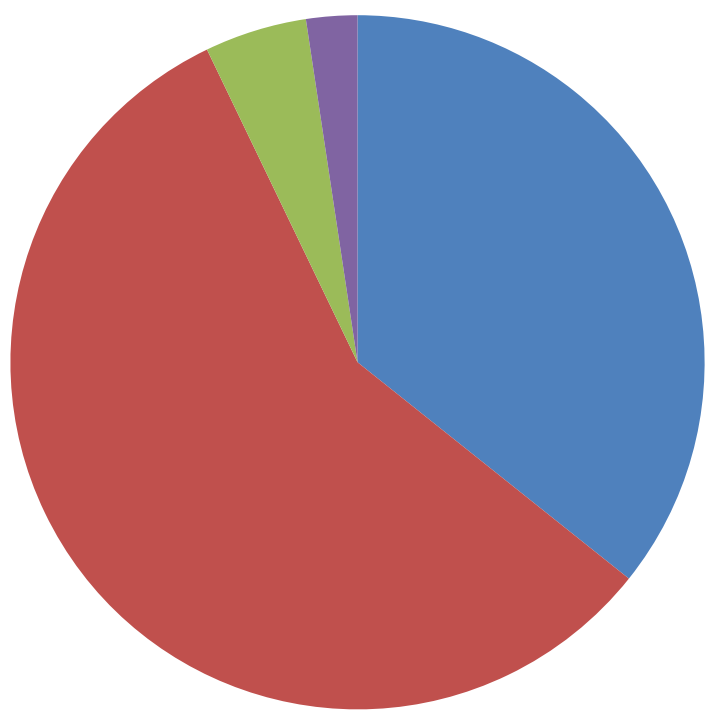

- 12 point

10 point

9 point

- 8 point

12 pt. font: 15 exhibitions

10 pt. font: 24 exhibitions

9 pt. font: 2 exhibitions

8 pt. font: 1 exhibition

\section{Conclusions}


Online exhibitions are an excellent way for academic libraries to display their unique collections to a global audience. This research identifies areas of strength and aspects which may need modification to align with accessibility guidelines, such as increasing font size. The aesthetics of the exhibitions introduced colour, wide-screen formats, and increased use of enlargeable images of artefacts over time. This reflects a more balanced approach to the inclusion of formalist and analyst design, a functional aesthetic and an increase in user-centred design. The results of this analysis also confirm that by enhancing some aspects of usability, exhibition creators will also increase the accessibility. The University of Otago Special Collections contain a vast amount of rare manuscripts, texts and images which are enjoyed by staff and students in physical exhibitions. By continuing to focus on a balance of image and text, and adhering to accessibility and usability guidelines in the future, these appealing and informative exhibitions will continue to broaden the University of Otago Library's global audience.

\section{Recommendations for future research}

1. Crowd-sourcing. Unlike the scattershot requests for financial support from online fundraising giants like Kickstarter and Go Fund me, crowd-sourcing within cultural heritage institutions requires finding the right volunteers for the project. Trevor Owens (2013) notes that transcription tasks which can be processed accurately using optical character recognition (OCR) are not appropriate for crowd-sourced heritage projects. Owens notes that it 'isn't about Sisyphean tasks; it is about providing meaningful ways for the public to enhance collections while more deeply 
engaging and exploring them'. By including volunteers in a project, the online exhibition is extended beyond simply browsing. As a tertiary institution, the University of Otago Special Collections has a wealth of untapped volunteers who could aid in transcription- particularly as this could both engage them with specific exhibitions, and may correspond with a university class, for example English, Classics or History undergraduates. While the University does at present run a 'Centre for the Book', and a yearly set of seminars relating to archiving, preservation and digitisation, crowd-sourced student transcribers would improve Special Collections user engagement even further, and may allow the University to retrospectively add to past online exhibitions by updating them with relevant material. This would also allow the exhibitions to be more dynamic- updates and improvements can overcome webpage inertia.

2. Integration of accessibility options for vision and hearing impaired patrons, such as ensuring all exhibitions are compatible with screen readers, and all images are provided with alt+access text links. Utilisation of a web accessibility assessor would be prudent for all exhibitions to ensure the broadest audience possible can be reached. Currently, the University of Otago Library has a website accessibility page (see: http://www.otago.ac.nz/library/accessibility/) advising short cut keys for eleven major sections of the website, in addition to a list of internet browser, Windows and Mac shortcuts. The Special Collections page and its exhibitions are not included in the shortcuts list at present. Due to the high volume of exhibitions44 as of January 2014 and by extension the vast amount of images and information 
contained within them specific shortcuts for the exhibitions main pages, introductions and cabinets would be useful for accessibility.

3. Russo and Watkins (2005) also list several ways in which the web interface has evolved. One way in which exhibitions could be more tailored to the user is by enabling audiences to 'save and personalise their visit' via dynamic database construction. Taken one step further, patrons could in future highlight and save to an exhibition folder their favourite images or information from an exhibition- thus creating a personalised exhibition within an exhibition.

4. While videos providing information about the collections, its benefactors and the Otakou Printing Press are currently available on the special collections exhibition page (see: http://www.otago.ac.nz/library/specialcollections/) video has not yet been used within individual exhibitions. Although Flash programming has been sued to some effect in Walt Whitman's Leaves of Grass this could be extended for future exhibitions.

5. This research project only assessed a small section of the vast amount of accessibility check-points recommended by the WCAG et al. A project focussing exclusively on accessibility for differently-abled patrons would elicit valuable information in order to improve online exhibitions. The scope of this could include: Audio captioning for vision-impaired patrons; a study of web coding within the exhibitions to ensure html and htmlx access, by utilising accessibility assessors such as Penn States AccessAbility tool; keyboard navigation as an alternative to mouse use; assessment of alt-text for all images, and correct headings for screen readers to ensure all aspects are accessible to vision impaired patrons; add a 'skip to main 
content' link on each page, if it contains a large amount of text. This will mean patrons using screen readers will not have to wait and listen to information that is not core; ensure the design template selected for the exhibition is accessible.

\section{References:}


Belcher, M. (1991). Exhibitions in Museums. Leicester: Leicester University Press.

Bernier. R. (2002). The uses of virtual museums: The French viewpoint'. Available at: www.archimuse.com/mw2002/papers/bernier/bernier.html

Cameron, F \& Kenderline, S. eds. (2007) Theorizing Digital Cultural Heritage. Massachusetts Institute of Technology: Cambridge, MA

Friedman, T. L (2005). The world is flat: A brief history of the globalised world in the $21^{\text {st }}$ century. London: Penguin Group.

Kalfatovic, M. R., \& American Library Association. (2002). Creating a winning online exhibition: A guide for libraries, archives, and museums. Chicago: American Library Association.

Kalfatovic , Martin. (2001). Online with the show. School Library Journal, Net Connect, 32.

Krug, Steve. Don't make me think, revisited: a common sense approach to Web usability. $3^{\text {rd }}$ ed. Berkeley, Calif. : New Riders 2014

Lester, P. (2006). Is the virtual exhibition the natural successor to the physical? Journal of the Society of Archivists, 27(1), 85-101

Liew, C. L. (2006). Online cultural heritage exhibitions: A survey of strategic issues. Program, 40(4), 372-388

Mellone, James T. and David J. Williams (2009) Applying best practices in web site redesign: the Queens College Libraries experience. Queens College Libraries, City University of New York, Flushing, New York, USA.

Milekic, Slavko. (2010). Towards tangible virtualities: Tangialities. In Cameron, F., \& Kenderdine, S. (Eds.) Theorizing digital cultural heritage: A critical discourse. (Pp. 369-388). Cambridge, Mass: MIT Press.

Muller, K. (2002). Going global: Reaching out for the online visitor (now, through the world-wide-web, museum resources can be accessed by a worldwide audience). MUSEUM NEWS, 81(5), 46-53.

National Information Standards Organization (U.S.) (2007) A framework of guidance for building good digital collections : a NISO recommended practice ( $3^{\text {rd }}$ ed.) Baltimore, MD : National Information Standards Organization (NISO), (C)2007.

Ongena, Guido Erik Huizer, Lidwien van de Wijngaert . (2012). Threats and opportunities for new audio-visual cultural heritage archive services: The Dutch case Telematics and 
Informatics, Volume 29, Issue 2, May 2012, Pages 156-165

Owens, Trevor. Digital Cultural Heritage and the Crowd Curator: The Museum Journal Volume 56, Issue 1, Article first published online: 7 Jan 2013.

Pang, Natalie and Schauder, Don. (2007) The Culture of Information Systems in KnowledgeCreating contexts: The role of User-Centered Design. In 'Use and Redesign in IS: Double Helix Relationships?; Informing Science Journal, vol.10.

Raward, Roslyn A. (2002) A Study of Best Practice Design Guidelines and the Development of a Usability Analysis Tool for the Evaluation of Australian Academic Library Websites. A thesis submitted in partial fulfilment of the requirements for the degree of Master of Arts at the University of Canberra. Canberra: September 2002.

Russo, Angelina and Watkins, Jerry (2005) Post-museum experiences: structured methods for audience engagement. Thwaites, H., Eds. Proceedings Eleventh International Conference on Virtual Systems and Multimedia, pages pp. 173-182, Brussels.

Shyam Sundar, S. et al (2013) User Experience of On-screen Interaction Techniques: An Experimental Investigation of Clicking, Sliding, Zooming, Hovering, Dragging, and Flipping. Human-Computer Interaction, 29:2, 109-152.

Silver, D. (1997). Interfacing American culture: the perils and potentials of virtual exhibitions. American Quarterly, 49(4), 825-850.

Stigter, Fleur (2009). Virtual communities in Europe: The European library approach. Program: Electronic Library and Information Systems, 43(3), 299-310.

Tonta, Yasar. Libraries and museums in the flat world: Are they becoming virtual destinations? Library Collections, Acquisitions, and Technical Services, Volume 32, Issue 1, 2008, Pages 1-9

Vandi, Claudio \& Elhadi Djebbari. (2011). How to create new services between library resources, museum exhibitions and virtual collections. Library Hi Tech News, 28(2), 15-19.

Witcomb, Andrea (2003). Reimagining the Museum: Beyond the Mausoleum. New York and London: Routledge.

\section{Web References}

The University of London- The Wallace Collection. (2013). Retrieved September 6, 2013, from

http://www.wallacecollection.org/interact/wallacelive

Smithsonian Institute: Online Exhibitions. (2013). Retrieved September 6, 2013, from http://www.sil.si.edu/SILPublications/Online-Exhibitions/ 
National Library of New Zealand: Online Exhibitions. (2013). Retrieved September 6, 2013, from

http://www.natlib.govt.nz/collections/online-exhibitions/

Library of Congress: Exhibitions. (2013). Retrieved September 6, 2013, from

http://www.loc.gov/exhibits/

Online Exhibitions (n.d.) In Wikipedia, The Free Encyclopedia. Retrieved September 6, 2013, from

http://en.wikipedia.org/wiki/Online exhibition

New York Public Library: Online Exhibitions. (2013). Retrieved September 6, 2013, from http://www.nypl.org/events/online-exhibitions

Auckland City Library- Shades of Grey Exhibitions. (2013). Retrieved September 6, 2013, from

http://www.aucklandcity.govt.nz/dbtw-wpd/virt-exhib/ShadesofGrey/index.asp

British Library: Online Gallery Exhibitions. (2013). Retrieved September 6, 2013, from http://www.bl.uk/onlinegallery/onlineex/index.html

Penn State University: Accessibility. (2014). Retrieved January 30, 2014.

http://accessibility.psu.edu/protocol

University Library, Special Collections Overview. Accessed November 17, 2013.

https://library.wiki.otago.ac.nz/images/6/6b/Special Collections Overview CDP and Ope rations 20130530.pdf

WCAG Guidelines: Wikipedia. Accessed January 31, 2013.

http://en.wikipedia.org/wiki/WCAG

\section{Bibliography}

Chamberlain, Paul and Yoxall, Alaster (2012) 'Of Mice and Men': The Role of Interactive Exhibitions as Research Tools for Inclusive Design. The Design Journal: volume 15, issue 1, pp 57-78.

Chua, A. Y. K., \& Goh, D. H. (2010). A study of web 2.0 applications in library websites. Library and Information Science Research, 32(3), 203-211.

Doherty , J . (2011). National library of Ireland: Digital resources. Choice, 48(6), 1048. García-Marco, Francisco-Javier. (2011). Libraries in the digital ecology: Reflections and 
trends. The Electronic Library, 29(1), 105-120.

Krishnamurthy, M. (2008). Open access, open source and digital libraries - A current trend in university libraries around the world. Program-Electronic Library and Information Systems, 42(1), 48-55.

Kroski, Ellyssa. (2008). Library mobile initiatives. Library Technology Reports, 44(5), 33

Krotoski, A. (2010). Libraries of the future: A hands-on exhibition shows how online tools are shaping the way we use knowledge. Nature, 468(7324)

Levinson, D. E. (2010). Library and archival exhibitions on the web.(http://www.sil.si.edu/SILPublications/Online-exhibitions/)(website overview). CHOICE: Current Reviews for Academic Libraries, 47(12), 2285

Levinson, D. E. (2011). Digital images online: Beinecke rare book \& manuscript library, Yale University. CHOICE: Current Reviews for Academic Libraries, 48(12)

McBride, Leah. (2006). National library exhibition commemorates rising online. Irish Times, pp.

Niegaard, H. (2011). Library space and digital challenges. LIBRARY TRENDS, 60(1), 174189.

Rubin, Victoria L., Yimin Chen, \& Lynne Marie Thorimbert. (2010). Artificially intelligent conversational agents in libraries. Library Hi Tech, 28(4), 496-522.

Saiki , Diana. (2008). Featuring clothing and textile collections online. Aslib Proceedings: New Information Perspectives, 60(2), 99-110.

Thatcher, Jim et.al (2006.) Web Accessibility: Web Standards and Regulatory Compliance Apress: Berkeley, CA

Tiffen, B., \& England, A. (2011). Engaging with clients and personalising services at UTS library: Measuring the value for libraries and their clients. Australian Library Journal, 60(3), 237-247

Zanin-Yost, A. (2010). Library 2.0: Blogs, wikis, and RSS to serve the library. Library Philosophy and Practice,

Zhou , Yuhong. (2009). The public library as the local gateway to knowledge: Shanghai library's information service for the 2010 world expo. Information Development, 25(2), 127-132.

\section{Appendix I: Analysis of 42 Exhibitions}




\begin{tabular}{|c|c|c|}
\hline Exhibition title & Overview & Analysis \\
\hline $\begin{aligned} & 1 . \begin{array}{l}\text { Portrait of a } \\
\text { gentleman scholar: }\end{array} \\
& \text { celebrating the life } \\
& \text { and legacy of } \\
& \text { Esmond de Beer } \\
& \text { 21 March - } 13 \text { June 2002 }\end{aligned}$ & $\begin{array}{l}\text { Aligns left. } \\
\text { Body: font size } 10 \\
\text { Heading: font size } 28 \\
\text { Exhibits listed but not displayed (collection } \\
\text { LC number included with provenance for } \\
\text { each artefact) Some images from the } \\
\text { opening of the live exhibition included. } \\
\text { Cabinets titled, but text only within } \\
\text { cabinets. }\end{array}$ & $\begin{array}{l}\text { Body font is too small, } \\
\text { and poses an } \\
\text { accessibility issue; } \\
\text { exhibit listing is } \\
\text { helpful- however, } \\
\text { links to images or } \\
\text { thumbnails from } \\
\text { cabinets would } \\
\text { improve the overall } \\
\text { exhibition. }\end{array}$ \\
\hline $\begin{aligned} & \text { 2. } \begin{array}{l}\text { Enlarging the } \\
\text { prospects of }\end{array} \\
& \text { happiness: European } \\
& \text { travel writing } \\
& \text { through the ages } \\
& \text { 21 June - 1 September 2002 }\end{aligned}$ & $\begin{array}{l}\text { Aligns left } \\
\text { Body: font size } 10 \\
\text { Heading: font size } 28 \\
\text { Cabinets titled; small links to images with } \\
\text { each artefact (not as thumbnail, just.jpg to } \\
\text { click.) }\end{array}$ & $\begin{array}{l}\text { Font size is too small, } \\
\text { however all cabinets } \\
\text { are clearly titled on } \\
\text { the left, and links to } \\
\text { images are large and } \\
\text { enhance the user } \\
\text { experience of the } \\
\text { exhibition. }\end{array}$ \\
\hline $\begin{array}{l}\text { 3. } \frac{\text { Unpacking Ruins: }}{\text { architecture from }} \\
\text { antiquity } \\
\text { 12 September - 28 November } \\
\text { 2002 }\end{array}$ & $\begin{array}{l}\text { Aligns left } \\
\text { Body: font size } 12 \text { Main page, } \\
10 \text { within exhibition } \\
\text { Heading: font size } 28 \\
\text { Cabinets titled small links to images with } \\
\text { each artefact (not as thumbnail, just jpg to } \\
\text { click.) }\end{array}$ & $\begin{array}{l}\text { Font size is too small, } \\
\text { however all cabinets } \\
\text { are clearly titled on } \\
\text { the left, and links to } \\
\text { images are large and } \\
\text { enhance the user } \\
\text { experience of the } \\
\text { exhibition. }\end{array}$ \\
\hline $\begin{array}{l}\text { 4. } \frac{\text { Rare Delights: recent }}{\frac{\text { additions to Special }}{\text { Collections }}} \\
\text { 13 December 2002 - 13 March } \\
2003\end{array}$ & $\begin{array}{l}\text { Aligns left } \\
\text { Body: font size } 12 \text { Main page, } \\
10 \text { within exhibition } \\
\text { Heading: font size } 28 \\
\text { Cabinets numbered- One image provided } \\
\text { per cabinet }\end{array}$ & $\begin{array}{l}\text { Font size } \\
\text { inconsistent- } 12 \mathrm{pt} . \\
\text { throughout the } \\
\text { exhibition would be } \\
\text { ideal for accessibility. } \\
\text { User-centered design } \\
\text { would also be } \\
\text { improved if cabinets } \\
\text { were titled in an } \\
\text { index in addition to } \\
\text { being numbered. }\end{array}$ \\
\hline $\begin{aligned} \text { 5. } \frac{\text { Cultivating Gardens: }}{\text { Practical garden }} \\
\frac{\text { advice through the }}{\text { ages }} \\
\text { 21 March - 27 June } 2003\end{aligned}$ & $\begin{array}{l}\text { Aligns left } \\
\text { Body: font size } 12 \text { Main page, } \\
10 \text { within exhibition } \\
\text { Heading: font size } 28 \\
\text { Cabinets numbered }\end{array}$ & $\begin{array}{l}\text { This exhibition is very } \\
\text { similar in design to } \\
\text { 'Rare Delights' and } \\
\text { thus the same } \\
\text { recommendations } \\
\text { apply }\end{array}$ \\
\hline $\begin{aligned} & \text { 6. } \frac{\text { Harmonizing my }}{\text { starting place: }} \\
& \frac{\text { Charles Brasch, }}{\text { patron, poet and }} \\
& \text { 4 July - } 17 \text { November } 2003\end{aligned}$ & $\begin{array}{l}\text { Whole page, centred. } \\
\text { Body: } \\
\text { Font size } 10 \text { within exhibition } \\
\text { Heading: font size } 18 \\
\text { Cabinets numbered, and on main page } \\
\text { three small images can be clicked on the } \\
\text { view three separate Brasch works. }\end{array}$ & $\begin{array}{l}\text { Font is too small, } \\
\text { cabinets would be } \\
\text { better as titled } \\
\text { instead of numbered } \\
\text { for ease of access, and } \\
\text { while the three } \\
\text { images on the main } \\
\text { page are useful in } \\
\text { illustrating Brasch's }\end{array}$ \\
\hline
\end{tabular}




\begin{tabular}{|c|c|c|}
\hline & & $\begin{array}{l}\text { work, larger versions } \\
\text { would be more } \\
\text { effective as the design } \\
\text { is too sparse- much of } \\
\text { the main page is } \\
\text { blank. The cabinets } \\
\text { and introduction are } \\
\text { better balanced in } \\
\text { terms of formalist vs. } \\
\text { analyst design, but } \\
\text { are overly 'wordy' } \\
\text { and would benefit } \\
\text { from pictures used in } \\
\text { each cabinet to be } \\
\text { clickable/enlargeable }\end{array}$ \\
\hline $\begin{array}{l}\text { 7. } \frac{\text { He tirohanga ki muri }}{\sim \text { A view of the past }} \\
25 \text { November } 2003-12 \text { March } \\
2004\end{array}$ & $\begin{array}{l}\text { Whole page, centred. } \\
\text { Body: } \\
\text { Font size } 12 \text { introduction, } \\
10 \text { within exhibition } \\
\text { Heading: font size } 18 \\
\text { Cabinets titled }\end{array}$ & $\begin{array}{l}\text { Well balanced full- } \\
\text { screen main page, } \\
\text { with appropriate } \\
\text { sized font, large image } \\
\text { at centre which } \\
\text { focusses the patron; } \\
\text { titled cabinets on the } \\
\text { left and right. Font } \\
\text { within cabinets is too } \\
\text { small, however many } \\
\text { high resolution } \\
\text { images/thumbnails } \\
\text { per cabinet can be } \\
\text { enlarged by the } \\
\text { patron, enhancing the } \\
\text { user experience. }\end{array}$ \\
\hline $\begin{aligned} & \text { 8. } \frac{\text { Glimpses of }}{\text { London's Past }} \\
& 23 \text { March - } 11 \text { June 2004 }\end{aligned}$ & $\begin{array}{l}\text { Whole page, centred. } \\
\text { Font size } 9 \text { introduction, } \\
10 \text { within exhibition, Index of cabinet titles } \\
\text { size } 14 \\
\text { Heading: font size } 48 \\
\text { Cabinets titled. }\end{array}$ & $\begin{array}{l}\text { Main body font too } \\
\text { small, however the } \\
\text { cabinets are titled and } \\
14 \text { pt. This exhibition } \\
\text { is centred and leaves } \\
\text { much grey space on a } \\
\text { wide screen monitor, } \\
\text { but the design itself is } \\
\text { well balanced } \\
\text { between images and } \\
\text { text. The magnify tool } \\
\text { is excellent on the } \\
\text { main page, and would } \\
\text { be highly useful with } \\
\text { the exhibition itself to } \\
\text { get a closer look at } \\
\text { artefacts-or indeed } \\
\text { other exhibitions }\end{array}$ \\
\hline 9. $\frac{41 \text { Stunning Books: }}{\text { A selection of }}$ & $\begin{array}{l}\text { Whole page, scrolling, index on right. } \\
\text { Body: } \\
\text { Font size } 8 \text { introduction, } \\
8 \text { within exhibition } \\
\text { Heading: font size } 24,\end{array}$ & $\begin{array}{l}\text { All cabinets are } \\
\text { numbered and titled, } \\
\text { with thumbnails for } \\
\text { ease of use. The } \\
\text { design uses red, black }\end{array}$ \\
\hline
\end{tabular}




\begin{tabular}{|c|c|c|}
\hline $\begin{aligned} \begin{array}{l}\text { modern private } \\
\text { press books }\end{array} \\
24 \text { June - } 10 \text { September 2004 }\end{aligned}$ & $\begin{array}{l}\text { page titles } 10 \\
\text { Cabinets- all } 41 \text { featured books are both } \\
\text { numbered and titled }\end{array}$ & $\begin{array}{l}\text { and white colour } \\
\text { contrasting to great } \\
\text { effect, centering the } \\
\text { title in red block } \\
\text { letters/numbers on a } \\
\text { white background. } \\
\text { While the font is too } \\
\text { small overall, the } \\
\text { scrolling index on the } \\
\text { left is visually } \\
\text { appealing, and each } \\
\text { cabinet contains high } \\
\text { resolution } \\
\text { enlargeable } \\
\text { thumbnails }\end{array}$ \\
\hline $\begin{array}{l}\text { 10. 'A Civilising Mission' } \\
\frac{\text { : New Zealanders }}{\text { and the Rhodes }} \\
\frac{\text { Scholarship 1904 - }}{2004} \\
\text { 20 September - 10 December } \\
2004\end{array}$ & $\begin{array}{l}\text { Whole page, centred, top half of screen. } \\
\text { Body: } \\
\text { Font size } 9 \text { within exhibition } \\
\text { Heading: font size } 18 \\
\text { Cabinets titled by Rhodes Scholar and year } \\
\text { of study at Oxford }\end{array}$ & $\begin{array}{l}\text { As it displays on a } \\
\text { wide screen monitor, } \\
\text { the introductory page } \\
\text { and subsequent } \\
\text { cabinets while } \\
\text { centred and too } \\
\text { small- usability is } \\
\text { enhanced via titled } \\
\text { index of each Scholar, } \\
\text { using a good example } \\
\text { of functional } \\
\text { aesthetics }\end{array}$ \\
\hline $\begin{array}{l}\text { 11. } \frac{\text { Straight Jackets: the }}{\text { Art of the Book }} \\
\text { Jacket } \\
20 \text { December } 2004 \text { - } 31 \text { March } \\
2005\end{array}$ & $\begin{array}{l}\text { Centre, page format. Fills more than one } \\
\text { screen (scrolling required for main page) } \\
\text { Body: } \\
\text { Font size } 10-12 \text { within exhibition } \\
\text { Heading: font size } 18 \\
\text { Cabinets titled and numbered }\end{array}$ & $\begin{array}{l}\text { A large amount of } \\
\text { scrolling required, } \\
\text { however this an } \\
\text { aesthetically } \\
\text { appealing exhibition } \\
\text { with a good balance of } \\
\text { image and } \\
\text { information }\end{array}$ \\
\hline $\begin{array}{l}\text { 12. "£100\& a butt of } \\
\frac{\text { sack yearly" The }}{\text { office of the poet }} \\
\text { 11 April - 24 June 2005 }\end{array}$ & $\begin{array}{l}\text { Whole page, centre image, small font with } \\
\text { index on left hand (no scrolling) } \\
\text { Body: } \\
\text { Font size } 10-12 \text { within exhibition } \\
\text { Heading: font size } 18 \\
\text { Cabinets titled }\end{array}$ & $\begin{array}{l}\text { Titled cabinets } \\
\text { enhance usability, and } \\
\text { some } 12 \text { pt font } \\
\text { within body of } \\
\text { exhibition aids } \\
\text { accessibility. Design is } \\
\text { functional, aesthetic } \\
\text { and didactic }\end{array}$ \\
\hline $\begin{aligned} & \text { 13. } \text { The Word on } \\
& \text { Modernism: How } \\
& \text { Books Aided a } \\
& \text { Revolution in Design } \\
& \text { 11 July - 23 } \text { September 2005 }\end{aligned}$ & $\begin{array}{l}\text { Similar to previous- whole page, image at } \\
\text { centre, index left, no scrolling. } \\
\text { Body: } \\
\text { Font size } 10-12 \text { within exhibition } \\
\text { Heading: font size } 18 \\
\text { Cabinets titled .Several Images do not work } \\
\text { ('No image available') - unclear whether } \\
\text { there were ever images to begin with. }\end{array}$ & $\begin{array}{l}\text { While the overall } \\
\text { design of this } \\
\text { exhibition integrates } \\
\text { good balance of the } \\
\text { formalist and analyst, } \\
\text { the small number of } \\
\text { images that do not } \\
\text { appear create gaps in } \\
\text { the patron } \\
\text { experience. } \\
\text { Informative: }\end{array}$ \\
\hline
\end{tabular}




\begin{tabular}{|c|c|c|}
\hline & & $\begin{array}{l}\text { evocative and } \\
\text { didactic. }\end{array}$ \\
\hline $\begin{array}{l}\text { 14. } \frac{\text { Walt Whitman's }}{\text { Leaves of Grass }} \\
17 \text { October } 2005-27 \text { January } \\
2006\end{array}$ & $\begin{array}{l}\text { Very effective. Whole page (screen) image } \\
\text { and text at centre, launch and about } \\
\text { buttons. Minimalist- no index until one } \\
\text { enters the exhibition. } \\
\text { Body: } \\
\text { Font size } 10-12 \text { within exhibition } \\
\text { Heading: font size } 18 \\
\text { Cabinets numbered and titled }\end{array}$ & $\begin{array}{l}\text { An excellent balance } \\
\text { of formalist and } \\
\text { analyst design, } \\
\text { utilising flash } \\
\text { technology form } \\
\text { 'falling leaves' which } \\
\text { float across the screen } \\
\text { as the patron opens } \\
\text { the exhibition. While } \\
\text { the size of the } \\
\text { cabinets are too small, } \\
\text { a larger font is used } \\
\text { over all in addition to } \\
\text { 'play' and 'pause' } \\
\text { button to navigate } \\
\text { each cabinet } \\
\text { enhances usability } \\
\text { and patron } \\
\text { experience }\end{array}$ \\
\hline $\begin{aligned} & \text { 15. } \frac{\text { West Meets East: }}{\text { Images of China and }} \\
& \frac{\text { Iapan, } 1570 \text { to } 1920}{10 \text { February - 26 May } 2006}\end{aligned}$ & $\begin{array}{l}\text { Aligned left- top left corner scrolling index } \\
\text { to right of box. Small font, small clickable } \\
\text { objects. } \\
\text { Body: } \\
\text { Font size } 10 \text { within exhibition } \\
\text { Heading: font size } 18 \\
\text { Cabinets numbered and titled }\end{array}$ & $\begin{array}{l}\text { Drop down } \\
\text { information over each } \\
\text { image is very difficult } \\
\text { to read (white box } \\
\text { and light grey font) }\end{array}$ \\
\hline $\begin{array}{l}\text { 16. The Black Art: Hand- } \\
\frac{\text { printing in the }}{\text { Bibliography Room, }} \\
\text { 1 June - } 25 \text { August } 2006\end{array}$ & $\begin{array}{l}\text { Aligned left- title banner with no index, just } \\
\text { clickable images. Divided into } 18 \text { cabinets, } \\
\text { no additional information. } \\
\text { Body: } \\
\text { Font size } 10 \text { within exhibition } \\
\text { Heading: font size } 18 \\
\text { Cabinets numbered and titled }\end{array}$ & $\begin{array}{l}\text { Additional } \\
\text { information on the } \\
\text { main page is sparse, } \\
\text { however the use of } \\
\text { image and the vast } \\
\text { amount if information } \\
\text { within each cabinet } \\
\text { create a good balance } \\
\text { of formalist and } \\
\text { analyst. }\end{array}$ \\
\hline $\begin{array}{l}\text { 17. In the Flesh. The } \\
\underline{\text { Monro Dynasty }} \\
\underline{1720-1846 .} \\
4 \quad \text { September - 1 December } \\
2006\end{array}$ & $\begin{array}{l}\text { Full page, small font. Aligns left, including } \\
\text { banner. Introduction is at centre, cabinets } \\
1-18 \text { and walls at left, each providing } \\
\text { further information on artefacts. } \\
\text { Body: } \\
\text { Font size } 9 \text { within exhibition } \\
\text { Headings: font size } 16-18 \\
\text { Cabinets numbered }\end{array}$ & $\begin{array}{l}\text { Well balanced, but } \\
\text { titles in addition to } \\
\text { enumeration for } \\
\text { cabinets would } \\
\text { enhance usability and } \\
\text { patron experience }\end{array}$ \\
\hline 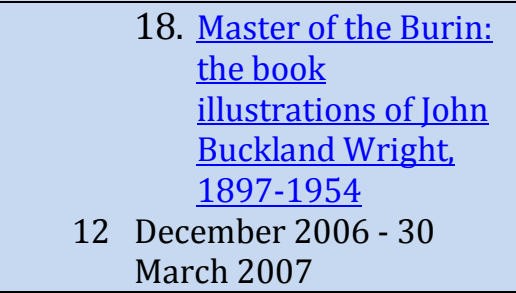 & $\begin{array}{l}\text { Image at the top. Full page, scrolling } \\
\text { introduction. This includes a foreword, } \\
\text { acknowledgements, references, and a link } \\
\text { to a chronological lifespan of the subject. } \\
\text { Cabinets and walls } 1-18 \text { aligned left, no } \\
\text { thumbnails. } \\
\text { Body: }\end{array}$ & $\begin{array}{l}\text { This is an evocative } \\
\text { and didactic } \\
\text { exhibition, with a high } \\
\text { level of aesthetic } \\
\text { appeal. }\end{array}$ \\
\hline
\end{tabular}




\begin{tabular}{|c|c|c|}
\hline & $\begin{array}{l}\text { Font size } 9-10 \text { within exhibition } \\
\text { Heading: font size } 14-16 \\
\text { Cabinets numbered }\end{array}$ & \\
\hline $\begin{array}{r}\text { 19. A Quick Stab at the } \\
\frac{\text { Eighteenth Century }}{11 \text { April to } 29 \text { June } 2007}\end{array}$ & $\begin{array}{l}\text { Aligns left, title/image/exhibition. Both title } \\
\text { and image are clickable for access to } \\
\text { introduction and references. Cabinets, walls } \\
\text { and vitrines aligned at top. No thumbnails, } \\
\text { main image clickable, which leads to } \\
\text { information on its source. } \\
\text { Body: } \\
\text { Font size } 9-10 \text { within exhibition } \\
\text { Heading: font size } 18 \\
\text { Cabinets numbered }\end{array}$ & $\begin{array}{l}\text { Font is too small, and } \\
\text { further use of images } \\
\text { would improve } \\
\text { aesthetics. }\end{array}$ \\
\hline $\begin{aligned} \text { 20. Linnaeus, Prince of } \\
\text { Botanists: His Works } \\
\text { and Legacy } \\
6 \text { July to } 28 \text { September } 2007\end{aligned}$ & $\begin{array}{l}\text { Aligned left, fine but large font. } \\
\text { Introduction is followed by a list of } \\
\text { references, cabinets at top and bottom. Two } \\
\text { reference links } \\
\text { Body: } \\
\text { Font size } 12-14 \text { within exhibition } \\
\text { Heading: font size } 12-18 \text {, somewhat hard to } \\
\text { read (cursive, light grey text) } \\
\text { Cabinets numbered }\end{array}$ & $\begin{array}{l}\text { Centering the } \\
\text { exhibition } \\
\text { introductory page } \\
\text { would improve } \\
\text { aesthetics somewhat, } \\
\text { however this utilises } \\
\text { images and } \\
\text { illustration to a high } \\
\text { level with appropriate } \\
\text { font sizing and } \\
\text { informative artefact } \\
\text { descriptions }\end{array}$ \\
\hline $\begin{array}{l}\text { 21. Initials: In the } \\
\text { Beginning... } \\
17 \text { October to } 14 \text { December } \\
2007\end{array}$ & $\begin{array}{l}\text { Full page, title aligns right. Cabinets at left } \\
\text { and bottom of screen, images and } \\
\text { introduction at centre. } \\
\text { Body: } \\
\text { Font size } 10-12 \text { within exhibition } \\
\text { Heading: font size } 18 \\
\text { Cabinets numbered }\end{array}$ & $\begin{array}{l}\text { Enumeration of } \\
\text { cabinets and small } \\
\text { font are the only } \\
\text { areas to improve in } \\
\text { this evocative and } \\
\text { didactic exhibition. }\end{array}$ \\
\hline $\begin{array}{l}\text { 22. } \frac{\text { RETROSPECTIVE: A }}{\text { look back at the }} \\
\frac{\underline{\text { last 21 Special }}}{\frac{\text { Collections }}{\text { exhibitions }}} \\
20 \text { December 2007 - 1 February } \\
2008\end{array}$ & $\begin{array}{l}\text { Centred, first } 21 \text { exhibitions. Index centre } \\
\text { left, with synopsis of each exhibition, an } \\
\text { image representing it and a link to each } \\
\text { exhibition. } \\
\text { Body: } \\
\text { Font size } 8-10 \text { within exhibition } \\
\text { Heading: font size } 48 \\
\text { Cabinets titled }\end{array}$ & $\begin{array}{l}\text { Titled cabinets make } \\
\text { the retrospective } \\
\text { exhibition easy to } \\
\text { peruse, however } \\
\text { enlarging font would } \\
\text { enhance accessibility. }\end{array}$ \\
\hline $\begin{aligned} & \text { 23. } \frac{\text { Rare Delights II: }}{\text { Recent Additions to }} \\
& \frac{\text { Special Collections }}{25 \text { February - } 25 \text { April } 2008}\end{aligned}$ & $\begin{array}{l}\text { Not really an exhibition, includes one link } \\
\text { to the exhibition poster. } \\
\text { Body: } \\
\text { Font size } 12 \text { on page } \\
\text { Heading: font size } 16 \\
\text { No cabinets }\end{array}$ & $\begin{array}{l}\text { The only exhibition of } \\
\text { all analysed which } \\
\text { lacks a didactic or } \\
\text { aesthetic appeal (see } \\
\text { in-depth analysis) }\end{array}$ \\
\hline $\begin{array}{l}\text { 24. Éire á Móradh: } \\
\frac{\text { Singing the Praises }}{\text { of Ireland }} \\
5 \text { May - } 22 \text { August } 2008\end{array}$ & $\begin{array}{l}\text { Full page, centred. Scrolling introduction, } \\
\text { cabinets at top and bottom } \\
\text { Body: } \\
\text { Font size } 10 \text { within exhibition } \\
\text { Heading: font size } 18 \\
\text { Cabinets numbered, includes scrolling } \\
\text { chronology }\end{array}$ & $\begin{array}{l}\text { A vibrant background } \\
\text { of green sets the } \\
\text { aesthetic tone for this } \\
\text { informative } \\
\text { exhibition. } \\
\text { Enumeration of } \\
\text { cabinets detracts }\end{array}$ \\
\hline
\end{tabular}




\begin{tabular}{|c|c|c|}
\hline & & $\begin{array}{l}\text { from usability } \\
\text { somewhat }\end{array}$ \\
\hline 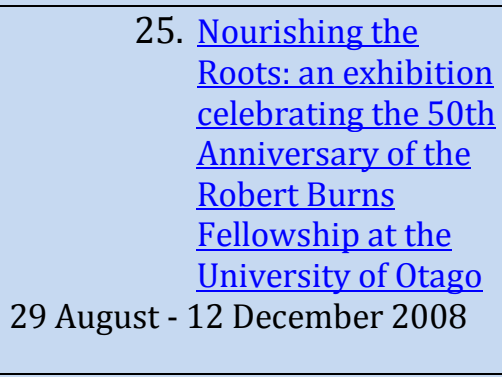 & $\begin{array}{l}\text { Centred, full page. Scrolling, title at top, } \\
\text { cabinets on left and clickable images to } \\
\text { enlarge list of Burns Fellows. } \\
\text { Body: } \\
\text { Font size } 10 \text { within exhibition } \\
\text { Headings: font size } 16-18 \\
\text { Cabinets titled }\end{array}$ & $\begin{array}{l}\text { Clickable images in } \\
\text { place of titles or } \\
\text { numbers is an } \\
\text { effective way of } \\
\text { demonstrating } \\
\text { cabinet contents } \\
\text { without the user } \\
\text { having to click into } \\
\text { each one. }\end{array}$ \\
\hline 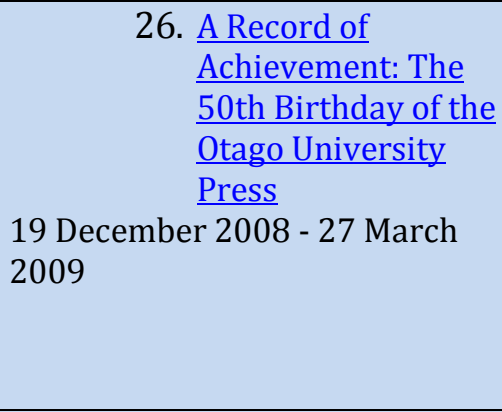 & $\begin{array}{l}\text { Centred, scrolling. Title and cabinets at the } \\
\text { top, two non-clickable images. Larger and } \\
\text { easier to read font. Cabinets at base of } \\
\text { screen, in addition to PDF and Word links } \\
\text { to full list of Otago University Press books } \\
\text { featured in the exhibition. } \\
\text { Body: } \\
\text { Font size } 10 \text { within exhibition } \\
\text { Headings: font size } 16-18 \\
\text { Cabinets numbered }\end{array}$ & $\begin{array}{l}\text { Integration of both } \\
\text { PDF and Microsoft } \\
\text { Word links to } \\
\text { exhibition list } \\
\text { enhance usability, } \\
\text { particularly for those } \\
\text { who do not have } \\
\text { access to Adobe } \\
\text { software. }\end{array}$ \\
\hline 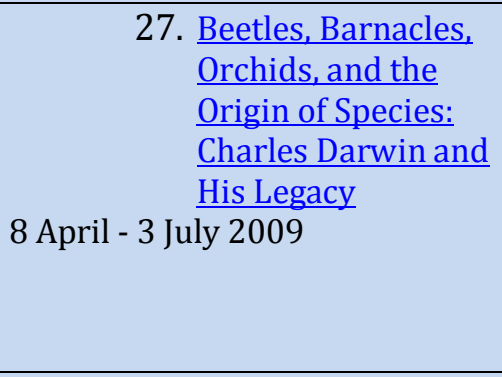 & $\begin{array}{l}\text { Centred, minimal scrolling required. Image } \\
\text { at the right, cabinets top and bottom. Left } \\
\text { aligned overview. Same font as previous } \\
\text { exhibition for overview text. } \\
\text { Body: } \\
\text { Font size } 10 \text { within exhibition } \\
\text { Headings: font size } 16-18 \\
\text { Cabinets numbered }\end{array}$ & $\begin{array}{l}\text { Cursive text in } \\
\text { heading could be } \\
\text { reflects the temporal } \\
\text { origins of the } \\
\text { exhibitions content, } \\
\text { however it is } \\
\text { somewhat fine- a } \\
\text { bolder type is } \\
\text { recommended. }\end{array}$ \\
\hline $\begin{array}{l}\frac{\text { 'I sat down in the }}{\text { evening to read...' }} \\
\text { Books from the } \\
\frac{\text { Library of Charles }}{\text { Brasch, Poet, 1909- }} \\
\text { 13 July - } 23 \text { October } 2009\end{array}$ & $\begin{array}{l}\text { The first proper 'wide screen' online } \\
\text { exhibition in the collection. No scrolling } \\
\text { required. Title at the top, cabinets at left, } \\
\text { overview at centre, image of Brasch at } \\
\text { right. } \\
\text { Body: } \\
\text { Font size } 10 \text { within exhibition } \\
\text { Headings: font size } 16-18 \\
\text { Cabinets titled }\end{array}$ & $\begin{array}{l}\text { This exhibition is } \\
\text { wide screen, and } \\
\text { sparse- it does not } \\
\text { overwhelm the } \\
\text { patron with too many } \\
\text { images and is not } \\
\text { overly text-heavy. }\end{array}$ \\
\hline $\begin{array}{l}\text { Heresy,Sedition,Obscenity: The } \\
\text { Book Challenged } \\
\text { 30 October } 2009-29 \\
\text { January } 2010\end{array}$ & $\begin{array}{l}\text { Centred, title at top. Poster and hand-list } \\
\text { available in PDF only. Introduction and all } \\
\text { cabinets scrollable with clickable images. } \\
\text { Images enlarge without patron needing to } \\
\text { leave page. Cabinets, vitrines and } \\
\text { reproduction rights at left. } \\
\text { Body: } \\
\text { Font size } 9-10 \text { within exhibition } \\
\text { Headings: font size } 16-18 \\
\text { Cabinets titled }\end{array}$ & $\begin{array}{l}\text { The manner in which } \\
\text { images can be } \\
\text { enlarged with one } \\
\text { click without leaving } \\
\text { the pain page } \\
\text { enhances usability. } \\
\text { Images are large and } \\
\text { high resolution. }\end{array}$ \\
\hline
\end{tabular}




\begin{tabular}{|c|c|c|}
\hline $\begin{array}{l}\text { Footnotes on Official History: } \\
\frac{\text { Celebrating Dr Hocken's }}{\text { Pamphlet Collection }} \\
\begin{array}{l}\text { 8 February } 2010 \text { - } 7 \text { May } \\
2010\end{array}\end{array}$ & $\begin{array}{l}\text { Centred, two titles at top of page, and left } \\
\text { top, in different font styles (one reflecting } \\
\text { the exhibition poster.) At left is an index of } \\
\text { numbered cabinets and walls. Non- } \\
\text { clickable image at top, centred. Cabinets in } \\
\text { same numbered format at bottom of page } \\
\text { also. } \\
\text { Body: } \\
\text { Font size } 12 \text { within exhibition } \\
\text { Headings: font size } 16-18 \\
\text { Cabinets numbered }\end{array}$ & $\begin{array}{l}\text { The introductory text } \\
\text { is somewhat } \\
\text { presumptive, stating } \\
\text { that a fact about Dr } \\
\text { Hocken 'is well } \\
\text { known'- this is } \\
\text { unlikely for a global } \\
\text { audience (or, indeed, } \\
\text { most patrons) }\end{array}$ \\
\hline $\begin{array}{l}\text { 31. ALL ABOARD! The Ernie } \\
\text { Webber Railway Collection } \\
\text { 14 May 2010- } 20 \text { August } 2010\end{array}$ & $\begin{array}{l}\text { Full page, centred, two titles. Cabinets at } \\
\text { the top, with a non-clickable image of Ernie } \\
\text { Webber. Informative and accessible } \\
\text { overview. No assumption about patron } \\
\text { prior knowledge. } \\
\text { Font size } 12 \text { within exhibition } \\
\text { Headings: font size } 16-48 \\
\text { Cabinets numbered }\end{array}$ & $\begin{array}{l}\text { Great use of colour, } \\
\text { appropriate font size } \\
\text { throughout and an } \\
\text { appealing and } \\
\text { instructive use of } \\
\text { both images and } \\
\text { information. }\end{array}$ \\
\hline $\begin{array}{l}\text { 32. Pulp Fiction } \\
27 \text { August to } 10 \text { December } 2010\end{array}$ & $\begin{array}{l}\text { Centred. Immediate immersion in tone of } \\
\text { exhibition, scrollable and clickable book } \\
\text { covers, followed by a full written overview } \\
\text { of the exhibition at the bottom. } \\
\text { Font size } 12 \text { within exhibition } \\
\text { Headings: font size } 16-32 \\
\text { Cabinets neither titled nor numbered on } \\
\text { main page- thumbnails of book covers are } \\
\text { clickable- these lead to cabinets which are } \\
\text { titled, numbered and richly detailed. }\end{array}$ & $\begin{array}{l}\text { Due to the sheer } \\
\text { volume of book } \\
\text { covers on the page, } \\
\text { quite a bit of scrolling } \\
\text { is required. This is a } \\
\text { minor issue within an } \\
\text { excellent exhibition } \\
\text { which combines a } \\
\text { high level of aesthetic } \\
\text { appeal with } \\
\text { fascinating details } \\
\text { about the authors of } \\
\text { the works. Easy } \\
\text { navigation and large } \\
\text { font creates easy } \\
\text { navigation for the } \\
\text { patron and a high } \\
\text { level of accessibility. }\end{array}$ \\
\hline $\begin{array}{l}\text { 33. Faces of Authorship: } \\
\text { Constructing the Author in } \\
\text { Medieval and Early Modern } \\
\text { Books } \\
\text { 17 December } 2010 \text { - } 25 \text { March } \\
2011\end{array}$ & $\begin{array}{l}\text { Full screen, centred, and the same layout as } \\
\text { Pulp Fiction. } \\
\text { Font size } 12 \text { within exhibition } \\
\text { Headings: font size } 16-32 \\
\text { Similar to Pulp fiction with clickable } \\
\text { thumbnails, however by hovering over each } \\
\text { image the cabinet title and a brief } \\
\text { statement about it appears }\end{array}$ & $\begin{array}{l}\text { At the top of the page } \\
\text { is a brief few lines of } \\
\text { introduction, followed } \\
\text { by clickable images } \\
\text { for the cabinets, and } \\
\text { at the bottom of the } \\
\text { page the } \\
\text { introduction/overvie } \\
\text { w continues. This } \\
\text { effectively lessens the } \\
\text { 'information } \\
\text { overload' of having } \\
\text { the full introduction } \\
\text { at the top, and gives } \\
\text { the patron options if } \\
\text { and when they want } \\
\text { to find out more }\end{array}$ \\
\hline
\end{tabular}




\begin{tabular}{|c|c|c|}
\hline $\begin{array}{l}\text { 34. Forging a Magical Landscape: } \\
\text { The Works of Robert Graves, Poet } \\
1 \text { April - } 17 \text { June } 2011\end{array}$ & $\begin{array}{l}\text { Centred, wide screen, full introduction at } \\
\text { top, clickable images as cabinets, similar to } \\
\text { previous two exhibitions. } \\
\text { Font size } 10 \text { introduction, } 12 \text { within } \\
\text { exhibition } \\
\text { Headings: font size } 16-18 \\
\text { Similar to Faces of Authorship with } \\
\text { clickable thumbnails, by hovering over each } \\
\text { image the cabinet title and a brief } \\
\text { statement about it appears }\end{array}$ & $\begin{array}{l}\text { Hover function } \\
\text { enhances patron use, } \\
\text { and the wide screen } \\
\text { layout and large font } \\
\text { also adheres to WCAG } \\
\text { accessibility } \\
\text { guidelines. }\end{array}$ \\
\hline $\begin{array}{l}\text { 35. Experimental Philosophy: old } \\
\text { and new } \\
1 \text { July - } 23 \text { September } 2011\end{array}$ & $\begin{array}{l}\text { Centred, scrollable, a high volume of text, } \\
\text { followed by small clickable images. These } \\
\text { then enlarge to high resolution versions at } \\
\text { centre of screen. The image at bottom of } \\
\text { screen remains static to emphasise } \\
\text { scrolling feature. } \\
\text { Font size } 10 \text { within exhibition } \\
\text { Headings: font size } 12-18 \\
\text { Scrolling down page required- headings for } \\
\text { what one assumes are each cabinet with } \\
\text { two to three clickable images for each one }\end{array}$ & $\begin{array}{l}\text { The cabinets are not } \\
\text { obvious, but one } \\
\text { assumes as one } \\
\text { scrolls down that } \\
\text { images and text are } \\
\text { 'in order' }\end{array}$ \\
\hline $\begin{array}{l}\text { 36. In Search of Scotland } \\
\text { 30 September - } 16 \text { December } \\
2011\end{array}$ & $\begin{array}{l}\text { Full page, title at the top. Images as } \\
\text { clickable cabinets. Brief introduction at the } \\
\text { top, more text at the base of the page. } \\
\text { Font size } 12 \text { within exhibition } \\
\text { Headings: font size } 14-18 \\
\text { Utilises clickable images, titles and } \\
\text { numbers to indicate cabinets, plus hover } \\
\text { function to indicate further information } \\
\text { about each image }\end{array}$ & $\begin{array}{l}\text { Arrows for next, } \\
\text { previous and home, } \\
\text { which clearly enhance } \\
\text { usability and } \\
\text { accessibility }\end{array}$ \\
\hline $\begin{array}{l}\text { 37. The Gentleman's Magazine: } \\
\text { The 18th century answer to } \\
\text { Google } \\
21 \text { December } 2011 \text { to } 16 \text { March } \\
2012\end{array}$ & $\begin{array}{l}\text { Wide-screen, centred title at the top of } \\
\text { page. This is followed by a four paragraph } \\
\text { introduction, and then clickable images of } \\
\text { exhibition artefacts divided by headers to } \\
\text { denote cabinets, vitrines and walls. A titled } \\
\text { index to the left is included } \\
\text { Font size } 12 \text { within exhibition } \\
\text { Headings: font size } 16-36 \\
\text { Cabinets titled on left, and also under } \\
\text { headings as one scrolls down page. }\end{array}$ & $\begin{array}{l}\text { Titled index is useful } \\
\text { for the patron, as } 18 \\
\text { cabinets un-titled } \\
\text { requires much } \\
\text { scrolling and clicking } \\
\text { if one is looking for } \\
\text { something in } \\
\text { particular. }\end{array}$ \\
\hline $\begin{array}{l}\text { 38. Ray Guns \& Rocket Ships. The } \\
\text { Fred Fastier Science Fiction } \\
\text { Collection } \\
23 \text { March - } 15 \text { June } 2012\end{array}$ & $\begin{array}{l}\text { Wide screen, centred title at the top. The } \\
\text { title reflects the exhibition poster design. } \\
\text { No cabinet indexes or titles, instead tiled } \\
\text { clickable images. Clicking opens a larger } \\
\text { version of the image with more detailed } \\
\text { information about the image or the theme it } \\
\text { relates to. At the base of the screen are PDF } \\
\text { links to the exhibition poster and hand-list. } \\
\text { Font size } 10 \text { within exhibition } \\
\text { Headings: font size } 16-18 \\
\text { Cabinets via clickable book covers, each } \\
\text { providing hover function with additional } \\
\text { information }\end{array}$ & $\begin{array}{l}\text { The three paragraph } \\
\text { introduction is in font } \\
\text { which jars with } \\
\text { gorgeous titles/ } \\
\text { images- however this } \\
\text { is the only design } \\
\text { issue in a well- } \\
\text { constructed } \\
\text { exhibition that } \\
\text { utilizes the diverse } \\
\text { book covers as an } \\
\text { aesthetic draw-card }\end{array}$ \\
\hline
\end{tabular}




\begin{tabular}{|c|c|c|}
\hline $\begin{array}{l}\text { 39. Charting the Land on the } \\
\text { Ocean: Pacific Exploration, } 1520 \text { - } \\
\underline{1876} \\
\text { 22 June - } 14 \text { September } 2012\end{array}$ & $\begin{array}{l}\text { Wide screen, centred. Five paragraph } \\
\text { introduction, followed by clickable images } \\
\text { (similar to 'Ray guns and Rocket Ships') } \\
\text { Includes cabinet index titled, not } \\
\text { numbered, at left. Each image when clicked } \\
\text { on can then go to 'next' or previous' when } \\
\text { opened. } \\
\text { Font size } 10 \text { within exhibition } \\
\text { Headings: font size } 14-18 \\
\text { Cabinets titled on left, and also under } \\
\text { headings as one scrolls down page. }\end{array}$ & $\begin{array}{l}\text { The use of numbering } \\
\text { is more appropriate } \\
\text { for a live exhibition } \\
\text { that an online one. } \\
\text { Excellent design- } \\
\text { usability would be } \\
\text { improved by } \\
\text { increasing font } \\
\text { however each cabinet } \\
\text { is well titled and } \\
\text { patron can either } \\
\text { scroll down page or } \\
\text { utilize index, thus } \\
\text { unobtrusive options }\end{array}$ \\
\hline $\begin{array}{l}\text { 40. Celebrating Charles Dickens } \\
\frac{(1812-1870)}{21 \text { September - } 13 \text { December }} \\
2012\end{array}$ & $\begin{array}{l}\text { Wide-screen, centred, four paragraph } \\
\text { introduction followed by an e-book link, } \\
\text { and links to PDF of exhibition poster and } \\
\text { hand-list. References are then listed, } \\
\text { followed by cabinets with clickable images. } \\
\text { The information on the page beside the } \\
\text { image is aligned left. On left top corner, 'III' } \\
\text { symbol denotes pull out/ down index } \\
\text { (titled). By clicking on the title of the } \\
\text { cabinet, the page then auto-scrolls to that } \\
\text { cabinet. } \\
\text { Font size } 10 \text { within exhibition } \\
\text { Headings: font size } 12-16 \\
\text { Cabinets titled on left, and also under } \\
\text { headings as one scrolls down page. }\end{array}$ & $\begin{array}{l}\text { Highly informative, } \\
\text { and a well-balanced } \\
\text { exhibition utilising } \\
\text { some colour, a wealth } \\
\text { of images and useful } \\
\text { information- } \\
\text { navigation is straight } \\
\text { forward due to layout } \\
\text { and titled index. }\end{array}$ \\
\hline $\begin{array}{l}\text { 41. From Pigskin to Paper: The } \\
\text { Art and Craft of Bookbinding } \\
20 \text { December } 2012-22 \text { March } \\
2013\end{array}$ & $\begin{array}{l}\text { Full screen, centred, serif font for } 3 \\
\text { paragraph introduction, below which are } \\
\text { PDF' links to the exhibition hand-list and } \\
\text { poster. No index, minimal text on main } \\
\text { page, which makes the artefacts themselves } \\
\text { more prominent. By clicking on each image, } \\
\text { similar to Ray guns and Rocket Ships } \\
\text { exhibition, additional information is } \\
\text { displayed in the centre of the screen, in } \\
\text { addition to an enlarged version of the } \\
\text { image. Some text in the descriptions is } \\
\text { replicated, as three separate images on the } \\
\text { main page may refer to the same text (an } \\
\text { image of the spine, flyleaves and front or } \\
\text { back cover, for example) } \\
\text { Font size } 12 \text { within exhibition } \\
\text { Headings: font size } 16-18 \\
\text { Cabinets via clickable book covers, each } \\
\text { providing hover function with additional } \\
\text { information }\end{array}$ & $\begin{array}{l}\text { The hover function } \\
\text { with the book covers } \\
\text { enhance usability in } \\
\text { this well designed, } \\
\text { aesthetically } \\
\text { appealing exhibition } \\
\text { which allows the } \\
\text { patron to 'browse' } \\
\text { book covers which } \\
\text { appeal for more } \\
\text { information about } \\
\text { their manufacture. }\end{array}$ \\
\hline $\begin{array}{l}\text { 42. Celebrating Pharmacy } \\
5 \text { April - } 25 \text { June } 2013\end{array}$ & $\begin{array}{l}\text { Similar to layout of 'Gentleman's Magazine', } \\
\text { however includes clickable arrow at below } \\
\text { right corner which auto-scrolls the patron } \\
\text { back to the top of the page. } \\
\text { Font size } 10 \text { within exhibition } \\
\text { Headings: font size } 12-18\end{array}$ & $\begin{array}{l}\text { While rather similar } \\
\text { to the design of } \\
\text { 'Gentlemans } \\
\text { Magazine', the } \\
\text { addition of the auto- } \\
\text { scroll function creates }\end{array}$ \\
\hline
\end{tabular}




\begin{tabular}{|l|l|l|}
\hline & $\begin{array}{l}\text { Cabinets titled on left, and also under } \\
\text { headings as one scrolls down page. }\end{array}$ & $\begin{array}{l}\text { a more accessible } \\
\text { exhibition, } \\
\text { particularly due to the } \\
\text { large volume of } \\
\text { information and } \\
\text { images presented. }\end{array}$ \\
\hline
\end{tabular}

\section{Appendix II: In-depth analysis}




\begin{tabular}{|c|c|}
\hline \multicolumn{2}{|c|}{ Portrait of a gentleman scholar: Celebrating the life and legacy of Esmond de Beer } \\
\hline $\begin{array}{l}\text { 1. Has a balance of formalist and analyst } \\
\text { methodology been achieved? (Lester:2006) }\end{array}$ & $\begin{array}{l}\text { This exhibition lacks balance due to too few images } \\
\text { available to view within each cabinet, however the } \\
\text { information provided is useful and relevant }\end{array}$ \\
\hline $\begin{array}{l}2 . \quad \text { Does the exhibition support patron } \\
\text { interactions that contribute to information transfer } \\
\text { and retention, and make the quality of virtually } \\
\text { presented information meet or exceed a real life } \\
\text { experience? (Milekic:2007) }\end{array}$ & $\begin{array}{l}\text { While much information on de Beer is provided, } \\
\text { the presentation lacks aesthetic appeal to enhance } \\
\text { patron interactions. It provides some images of the } \\
\text { live exhibitions opening and speakers present, } \\
\text { however, evoking some aspects of the physical } \\
\text { exhibition. }\end{array}$ \\
\hline $\begin{array}{l}\text { 3. How can the exhibition be assessed in } \\
\text { terms of Kalfatovic's five types of online exhibition: } \\
\text { is it aesthetic, emotive, evocative, didactic or } \\
\text { entertaining, or a composite of several of these } \\
\text { definitions? }\end{array}$ & $\begin{array}{l}\text { Primarily didactic, lacking in aesthetic appeal, } \\
\text { although the main page and small number of } \\
\text { images included are evocative to a small level }\end{array}$ \\
\hline $\begin{array}{l}4 . \quad \text { Is the exhibition maintained and actively } \\
\text { managed to ensure all links are accessible to } \\
\text { patrons? }\end{array}$ & $\begin{array}{l}\text { Not all links function correctly. The link to 'Otago } \\
\text { Daily Times article 19 March 2002' results in error } \\
\text { page. } \\
\text { All other links function correctly (most are from } \\
\text { within the University, not external links) }\end{array}$ \\
\hline $\begin{array}{l}5 . \quad \text { Is the design such that it is easy to navigate } \\
\text { and does not contain too much or too sparse a } \\
\text { range of artefacts per page? }\end{array}$ & $\begin{array}{l}\text { This exhibition is primarily text based- there is a lot } \\
\text { to read, and very few images or thumbnails of } \\
\text { cabinet artefacts to peruse. The small font is } \\
\text { challenging, however the exhibition utilises titled } \\
\text { cabinets and headings on each page. }\end{array}$ \\
\hline $\begin{array}{l}\text { 6. Is the exhibition accessible to persons with } \\
\text { disabilities, including adaptive technology? }\end{array}$ & $\begin{array}{l}\text { Like all of the exhibitions analysed, zoom capability } \\
\text { to enlarge font and images is available, however } \\
\text { font size itself is too small by WCAG accessibility } \\
\text { standards and font could be bolder. }\end{array}$ \\
\hline $\begin{array}{l}7 . \quad \text { Does the exhibition provide usage data and } \\
\text { other data to assess standardization and } \\
\text { usefulness? }\end{array}$ & $\begin{array}{l}\text { No usage data is provided on this or any of the } \\
\text { exhibitions. }\end{array}$ \\
\hline $\begin{array}{l}\text { 8. How does the exhibition reflect local and } \\
\text { national culture, and the purpose of the special } \\
\text { collections? }\end{array}$ & $\begin{array}{l}\text { Local culture- the De Beer gallery is where Special } \\
\text { Collections live exhibitions take place. This } \\
\text { inaugural online exhibition reflects the life } \\
\text { achievements of De Beer, a Dunedin scholar whose } \\
\text { generosity helps to maintain the collections. }\end{array}$ \\
\hline \multicolumn{2}{|c|}{ Rare Delights: Recent additions to Special Collections } \\
\hline $\begin{array}{l}\text { 1. Has a balance of formalist and analyst } \\
\text { methodology been achieved? (Lester:2006) }\end{array}$ & $\begin{array}{l}\text { To an extent. While there are more images available } \\
\text { than the first exhibition, they are primarily just } \\
\text { clickable buttons as opposed to thumbnails or } \\
\text { images which can be enlarged further. }\end{array}$ \\
\hline $\begin{array}{l}2 . \quad \text { Does the exhibition support patron } \\
\text { interactions that contribute to information transfer }\end{array}$ & $\begin{array}{l}\text { Some broken links and a lack of images inhibit the } \\
\text { exhibition, detracting from patron experience. }\end{array}$ \\
\hline
\end{tabular}




\begin{tabular}{|c|c|}
\hline $\begin{array}{l}\text { and retention, and make the quality of virtually } \\
\text { presented information meet or exceed a real life } \\
\text { experience? (Milekic:2007) }\end{array}$ & \\
\hline $\begin{array}{l}\text { 3. How can the exhibition be assessed in } \\
\text { terms of Kalfatovic's five types of online exhibition: } \\
\text { is it aesthetic, emotive, evocative, didactic or } \\
\text { entertaining, or a composite of several of these } \\
\text { definitions? }\end{array}$ & $\begin{array}{l}\text { Didactic and evocative. This exhibition contains } \\
\text { much informative detail and is somewhat aesthetic. }\end{array}$ \\
\hline $\begin{array}{l}4 . \quad \text { Is the exhibition maintained and actively } \\
\text { managed to ensure all links are accessible to } \\
\text { patrons? }\end{array}$ & $\begin{array}{l}\text { No. The exhibition includes many links to outside } \\
\text { academic libraries, several of which do not lead } \\
\text { directly to what is listed. For example, in } \\
\text { The cabinet titled 'The Bard and the Apothecary', a } \\
\text { link is listed as: } \\
\text { The English physitian: or an astrologo-physical } \\
\text { discourse of the vulgar herbs of this nation, which } \\
\text { takes the patron to: } \\
\text { http://library.medicine.yale.edu/ } \\
\text { which is the main page of the Harvey Cushing/John } \\
\text { Hay Whitney Medical Library. The correct link } \\
\text { should be: } \\
\text { http://doc.med.yale.edu/historical- } \\
\text { old/culpeper/culpeper.htm } \\
\text { Other links either do not work: } \\
\text { Nuremberg Chronicle table of contents } \\
\text { Or garner a } 404 \text { not found error page: } \\
\text { Print and the Book; } \\
\text { Images from the book from Taschen Publishers; } \\
\text { In 'Darwin's Letters', the first two links work: } \\
\text { - Literature of Charles Darwin: The Voyage of the } \\
\text { Beagle, Origin of Species and The Descent of Man. } \\
\text { - The C. Warren Irvin, Jr., Collection of Charles } \\
\text { Darwin and Darwiniana } \\
\text { However the third takes the patron to a page } \\
\text { indicating the link may be out of date: } \\
\text { Darwin Correspondence Project } \\
\text { Similarly, the 'Bird-man' cabinet on John James } \\
\text { Audubon has one link which is broken: } \\
\text { http://rylibweb.man.ac.uk/data1/dg/exhibition/bi } \\
\text { rds/\#list } \\
\text { the link in Renaissance man- John Cage still works } \\
\text { Museum of Contemporary Art } \\
\text { The link to Prints from the New Bath Guide in the } \\
\text { cabinet 'The Satirists' takes the patron to what used } \\
\text { to be the correct domain name, which has clearly } \\
\text { since been sold. }\end{array}$ \\
\hline
\end{tabular}




\begin{tabular}{|c|c|}
\hline $\begin{array}{l}5 . \quad \text { Is the design such that it is easy to navigate } \\
\text { and does not contain too much or too sparse a } \\
\text { range of artefacts per page? }\end{array}$ & $\begin{array}{l}\text { Similar to the first exhibition, however has } \\
\text { numbered cabinets at base of page and some links } \\
\text { to images from cabinets which can be enlarged and } \\
\text { made easy to view. Text is very small, and there is a } \\
\text { lot of it- navigation by cabinet is ok but could be } \\
\text { improved via titles and enlarged font. }\end{array}$ \\
\hline $\begin{array}{l}\text { 6. Is the exhibition accessible to persons with } \\
\text { disabilities, including adaptive technology? }\end{array}$ & $\begin{array}{l}\text { Titled cabinets and headings improve accessibility, } \\
\text { however small body font creates issues for vision- } \\
\text { impaired users. }\end{array}$ \\
\hline $\begin{array}{l}7 . \quad \text { Does the exhibition provide usage data } \\
\text { and other data to assess standardization and } \\
\text { usefulness? }\end{array}$ & $\begin{array}{l}\text { Not applicable (see Portrait of a Gentleman Scholar: } \\
\text { celebrating the life and legacy of Esmond de Beer) }\end{array}$ \\
\hline $\begin{array}{l}\text { 8. How does the exhibition reflect local and } \\
\text { national culture, and the purpose of the special } \\
\text { collections? }\end{array}$ & $\begin{array}{l}\text { The exhibition presents a variety of Special } \\
\text { Collection rare acquisitions and donations, so spans } \\
\text { both local and international culture. }\end{array}$ \\
\hline \multicolumn{2}{|c|}{ He tirohanga ki muri: A view of the past } \\
\hline $\begin{array}{l}\text { 1. Has a balance of formalist and analyst } \\
\text { methodology been achieved? (Lester:2006) }\end{array}$ & $\begin{array}{l}\text { Yes- text and image are perfectly balanced, with } \\
\text { subtle and appropriate use of colour (red, black, } \\
\text { white) to reflect Maori traditional culture. }\end{array}$ \\
\hline $\begin{array}{l}2 . \quad \text { Does the exhibition support patron } \\
\text { interactions that contribute to information transfer } \\
\text { and retention, and make the quality of virtually } \\
\text { presented information meet or exceed a real life } \\
\text { experience? (Milekic:2007) }\end{array}$ & $\begin{array}{l}\text { At the time it was first made available online, the } \\
\text { links would have been functional and thus } \\
\text { contributed to information retention and an over- } \\
\text { all illuminating experience for the patron. }\end{array}$ \\
\hline $\begin{array}{l}\text { 3. How can the exhibition be assessed in } \\
\text { terms of Kalfatovic's five types of online exhibition: } \\
\text { is it aesthetic, emotive, evocative, didactic or }\end{array}$ & $\begin{array}{l}\text { Didactic, aesthetic, evocative- excellent use of } \\
\text { images contribute to the aesthetic affect, and titled }\end{array}$ \\
\hline
\end{tabular}




\begin{tabular}{|c|c|}
\hline $\begin{array}{l}\text { entertaining, or a composite of several of these } \\
\text { definitions? }\end{array}$ & $\begin{array}{l}\text { cabinets aid functionality and usability via didactic } \\
\text { method. }\end{array}$ \\
\hline $\begin{array}{l}4 . \quad \text { Is the exhibition maintained and actively } \\
\text { managed to ensure all links are accessible to } \\
\text { patrons? }\end{array}$ & $\begin{array}{l}\text { All links still function except for Ngā Tāngata } \\
\text { Taumata Rau- } 404 \text { not found. }\end{array}$ \\
\hline $\begin{array}{l}5 . \quad \text { Is the design such that it is easy to navigate } \\
\text { and does not contain too much or too sparse a } \\
\text { range of artefacts per page? }\end{array}$ & $\begin{array}{l}\text { Well balanced between use of images and text, } \\
\text { neither of which overwhelm the viewer. The } \\
\text { exhibition is simple to navigate as cabinets and } \\
\text { images are titled and lists to the right and left. All } \\
\text { clickable images can be enlarged considerably } \\
\text { (filling the centre of the screen, } 2 / 3 \mathrm{rds} \text { ) }\end{array}$ \\
\hline $\begin{array}{l}\text { 6. Is the exhibition accessible to persons with } \\
\text { disabilities, including adaptive technology? }\end{array}$ & $\begin{array}{l}\text { Somewhat, although larger font would enhance the } \\
\text { experience. }\end{array}$ \\
\hline $\begin{array}{l}7 . \quad \text { Does the exhibition provide usage data and } \\
\text { other data to assess standardization and } \\
\text { usefulness? }\end{array}$ & $\begin{array}{l}\text { Not applicable (see Portrait of a Gentleman Scholar: } \\
\text { celebrating the life and legacy of Esmond de Beer) }\end{array}$ \\
\hline $\begin{array}{l}\text { 8. How does the exhibition reflect local and } \\
\text { national culture, and the purpose of the special } \\
\text { collections? }\end{array}$ & $\begin{array}{l}\text { By presenting local and national information on } \\
\text { Maori culture, the exhibition provides a window } \\
\text { onto the past via historical documents and also } \\
\text { references external links where patrons can learn } \\
\text { more about Maori and New Zealand history. }\end{array}$ \\
\hline
\end{tabular}

\begin{tabular}{|l|l|}
\hline \multicolumn{2}{|c|}{ Glimpses of London's Past } \\
\hline $\begin{array}{l}\text { 1. Has a balance of formalist and analyst } \\
\text { methodology been achieved? (Lester:2006) }\end{array}$ & $\begin{array}{l}\text { Yes, via the excellent use of images the patron is } \\
\text { immediately drawn in. The exhibition utilises } \\
\text { functional design while allowing patrons to explore } \\
\text { and enlarge cabinet artefacts for closer inspection. }\end{array}$ \\
\end{tabular}




\begin{tabular}{|c|c|}
\hline $\begin{array}{l}2 . \quad \text { Does the exhibition support patron } \\
\text { interactions that contribute to information transfer } \\
\text { and retention, and make the quality of virtually } \\
\text { presented information meet or exceed a real life } \\
\text { experience? (Milekic:2007) }\end{array}$ & $\begin{array}{l}\text { The use of the 'magnify tool' on the mail page is } \\
\text { excellent, and creates a user experience which in } \\
\text { some ways exceeds real life in the detail it } \\
\text { provides. }\end{array}$ \\
\hline $\begin{array}{l}\text { 3. How can the exhibition be assessed in } \\
\text { terms of Kalfatovic's five types of online exhibition: } \\
\text { is it aesthetic, emotive, evocative, didactic or } \\
\text { entertaining, or a composite of several of these } \\
\text { definitions? }\end{array}$ & $\begin{array}{l}\text { Aesthetic, didactic, evocative, entertaining- this } \\
\text { exhibitions functional design and informative detail } \\
\text { draw in the patron. }\end{array}$ \\
\hline $\begin{array}{l}\text { 4. Is the exhibition maintained and actively } \\
\text { managed to ensure all links are accessible to } \\
\text { patrons? }\end{array}$ & $\begin{array}{l}\text { All links work, save www.molas.org.uk which re- } \\
\text { directs patrons to the correct new address. }\end{array}$ \\
\hline $\begin{array}{l}5 . \quad \text { Is the design such that it is easy to navigate } \\
\text { and does not contain too much or too sparse a } \\
\text { range of artefacts per page? }\end{array}$ & $\begin{array}{l}\text { A good balance of image and text, with a magnify } \\
\text { tool on the main page an excellent feature that is } \\
\text { easy to use, by simply hovering over the image. } \\
\text { This tool would be useful within the exhibition } \\
\text { images, as several contain small text. Which each } \\
\text { image can be enlarged, the magnify tool would } \\
\text { enhance the patrons experience. }\end{array}$ \\
\hline $\begin{array}{l}\text { 6. Is the exhibition accessible to persons with } \\
\text { disabilities, including adaptive technology? }\end{array}$ & $\begin{array}{l}\text { Via the magnify and zoom tools, however small text } \\
\text { once again detracts from an over-all effective } \\
\text { exhibition }\end{array}$ \\
\hline $\begin{array}{l}7 . \quad \text { Does the exhibition provide usage data and } \\
\text { other data to assess standardization and } \\
\text { usefulness? }\end{array}$ & $\begin{array}{l}\text { Not applicable (see Portrait of a Gentleman Scholar: } \\
\text { celebrating the life and legacy of Esmond de Beer) }\end{array}$ \\
\hline $\begin{array}{l}\text { 8. How does the exhibition reflect local and } \\
\text { national culture, and the purpose of the special } \\
\text { collections? }\end{array}$ & $\begin{array}{l}\text { The exhibition subject matter is London, so is } \\
\text { international in theme, yet does reflect Special } \\
\text { Collections purpose in its exhibition and } \\
\text { preservation of rare or fragile material. }\end{array}$ \\
\hline
\end{tabular}




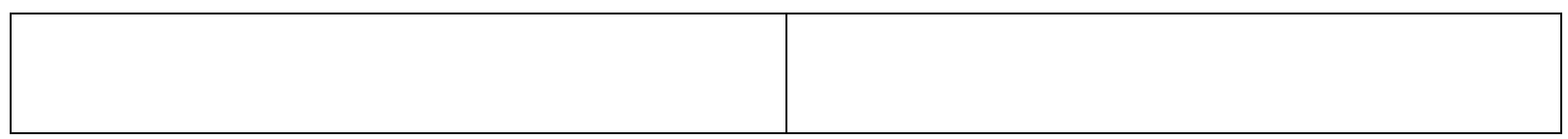

\begin{tabular}{|c|c|}
\hline \multicolumn{2}{|c|}{ Walt Whitman's Leaves of Grass } \\
\hline $\begin{array}{l}\text { 1. Has a balance of formalist and analyst } \\
\text { methodology been achieved? (Lester:2006) }\end{array}$ & $\begin{array}{l}\text { Yes- an excellent format for accessing Whitman's } \\
\text { works, detailing his life and achievements via } \\
\text { image and text without overwhelming the patron } \\
\text { with either. Navigation and design is such that the } \\
\text { patron can 'wander through' the online exhibition } \\
\text { perusing cabinets as thumbnails in order or by } \\
\text { interest. }\end{array}$ \\
\hline $\begin{array}{l}\text { Does the exhibition support patron } \\
\text { interactions that contribute to information transfer } \\
\text { and retention, and make the quality of virtually } \\
\text { presented information meet or exceed a real life } \\
\text { experience? (Milekic:2007) }\end{array}$ & $\begin{array}{l}\text { Yes- this exhibition was collaborative effort, and } \\
\text { draws on flash technology to appeal to the patron } \\
\text { and hover and scroll navigation to access materials. }\end{array}$ \\
\hline $\begin{array}{l}\text { 3. How can the exhibition be assessed in } \\
\text { terms of Kalfatovic's five types of online exhibition: } \\
\text { is it aesthetic, emotive, evocative, didactic or } \\
\text { entertaining, or a composite of several of these } \\
\text { definitions? }\end{array}$ & $\begin{array}{l}\text { Aesthetic, Emotive and Didactic, this exhibition } \\
\text { utilises design to great effect creating an emotive } \\
\text { space before the patron clicks 'launch'. Like an } \\
\text { entrance to a physical exhibition, this conveys a } \\
\text { sense of the exhibitions poetic theme from the } \\
\text { outset. }\end{array}$ \\
\hline $\begin{array}{l}\text { 4. Is the exhibition maintained and actively } \\
\text { managed to ensure all links are accessible to } \\
\text { patrons? }\end{array}$ & $\begin{array}{l}\text { This exhibition functions perfectly as it does not } \\
\text { contain any external links, and utilises flash to view } \\
\text { all cabinets. This exhibition is a collaborative effort } \\
\text { between the University of Otago Special } \\
\text { Collections, the Dunedin Public Library, and } \\
\text { Professor Joel Myerson, a Whitman Scholar from } \\
\text { the University of South Carolina. }\end{array}$ \\
\hline $\begin{array}{l}5 . \quad \text { Is the design such that it is easy to navigate } \\
\text { and does not contain too much or too sparse a } \\
\text { range of artefacts per page? }\end{array}$ & $\begin{array}{l}\text { Yes- a good balance of artefacts that could only be } \\
\text { improved by increasing the overall size of the } \\
\text { exhibition as it displays onscreen. }\end{array}$ \\
\hline
\end{tabular}




\begin{tabular}{|l|l|}
\hline $\begin{array}{l}\text { 6. Is the exhibition accessible to persons with } \\
\text { disabilities, including adaptive technology? }\end{array}$ & $\begin{array}{l}\text { This exhibition would benefit from larger font, but } \\
\text { is overall a good balance of unobtrusive colour } \\
\text { which is an appropriate visual background for } \\
\text { those with low vision. }\end{array}$ \\
\hline $\begin{array}{l}\text { 7. Does the exhibition provide usage data and } \\
\text { other data to assess standardization and } \\
\text { usefulness? }\end{array}$ & $\begin{array}{l}\text { Not applicable (see Portrait of a Gentleman Scholar: } \\
\text { celebrating the life and legacy of Esmond de Beer) }\end{array}$ \\
\hline $\begin{array}{l}\text { 8. How does the exhibition reflect local and } \\
\text { national culture, and the purpose of the special } \\
\text { collections? }\end{array}$ & $\begin{array}{l}\text { This exhibition reflects the collegial and } \\
\text { collaborative nature of Special Collections. }\end{array}$ \\
\hline \multicolumn{2}{|c|}{}
\end{tabular}

\begin{tabular}{|l|l|}
\hline \multicolumn{2}{|c|}{ A Quick Stab at the Eighteenth Century } \\
\hline $\begin{array}{l}\text { 1. Has a balance of formalist and analyst } \\
\text { methodology been achieved? (Lester:2006) }\end{array}$ & $\begin{array}{l}\text { Yes, although broken links detract from the analyst } \\
\text { aspect. The design of the main page is engaging and } \\
\text { appealing, using a charcoal and red colour palette } \\
\text { which reflects the exhibitions theme of a 'quick } \\
\text { stab'. }\end{array}$ \\
\hline $\begin{array}{l}\text { Does the exhibition support patron } \\
\text { interactions that contribute to information transfer } \\
\text { and retention, and make the quality of virtually } \\
\text { presented information meet or exceed a real life } \\
\text { experience? (Milekic:2007) }\end{array}$ & $\begin{array}{l}\text { Yes, however broken links inhibit user experience } \\
\text { of the exhibition. }\end{array}$ \\
\hline $\begin{array}{l}\text { How can the exhibition be assessed in } \\
\text { terms of Kalfatovic's five types of online exhibition: } \\
\text { is it aesthetic, emotive, evocative, didactic or } \\
\text { entertaining, or a composite of several of these } \\
\text { definitions? }\end{array}$ & $\begin{array}{l}\text { Aesthetic, didactic and entertaining, the design } \\
\text { reflects the subject matter well. }\end{array}$ \\
\hline $\begin{array}{l}\text { Is the exhibition maintained and actively } \\
\text { managed to ensure all links are accessible to } \\
\text { patrons? }\end{array}$ & $\begin{array}{l}\text { The link to the Oxford Dictionary of National } \\
\text { Biography (external) functions correctly. However, } \\
\text { all four University of Otago library catalogue links } \\
\text { lead to the same place- not the specific text, but the } \\
\text { library search box. This may be due to a recent } \\
\text { upgrade of University of Otago Library resources } \\
\text { from Voyager to Alma, thus nullifying previous }\end{array}$ \\
\hline
\end{tabular}




\begin{tabular}{|c|c|}
\hline & $\begin{array}{l}\text { links and requiring the patron to copy and paste } \\
\text { the link information into the search box. } \\
\text { Eighteenth-century Britain, 1688-1783. } \\
\text { Houndmills, Basingstoke, Hampshire; New York: } \\
\text { Palgrave, } 2001 . \\
\text { John Brewer, The Pleasures of the Imagination: } \\
\text { English Culture in the Eighteenth Century. New } \\
\text { York: Farrar Straus Giroux, } 1997 . \\
\text { H. T. Dickinson (ed.), A Companion to Eighteenth- } \\
\text { Century Britain. London: Blackwell Publishing, } \\
\text { 2002. } \\
\text { Juliet Gardiner and Neil Wenborn (eds.), The } \\
\text { Columbia Companion to British History. New York: } \\
\text { Columbia University Press, } 1997 .\end{array}$ \\
\hline $\begin{array}{l}5 . \quad \text { Is the design such that it is easy to navigate } \\
\text { and does not contain too much or too sparse a } \\
\text { range of artefacts per page? }\end{array}$ & Refer to 'Rare Delights 1' \\
\hline $\begin{array}{l}\text { 6. Is the exhibition accessible to persons with } \\
\text { disabilities, including adaptive technology? }\end{array}$ & Refer to 'Rare Delights 1' \\
\hline $\begin{array}{l}\text { 7. Does the exhibition provide usage data and } \\
\text { other data to assess standardization and } \\
\text { usefulness? }\end{array}$ & $\begin{array}{l}\text { Not applicable (see Portrait of a Gentleman Scholar: } \\
\text { celebrating the life and legacy of Esmond de Beer) }\end{array}$ \\
\hline $\begin{array}{l}\text { 8. How does the exhibition reflect local and } \\
\text { national culture, and the purpose of the special } \\
\text { collections? }\end{array}$ & Refer to 'A Glimpse of Londons Past' \\
\hline
\end{tabular}

\begin{tabular}{|l|l|}
\hline \multicolumn{2}{|c|}{ Rare Delights II: Recent Additions to Special Collections } \\
\hline $\begin{array}{l}\text { 1. Has a balance of formalist and analyst } \\
\text { methodology been achieved? (Lester:2006) }\end{array}$ & Not applicable- neither formalist nor analyst \\
\hline $\begin{array}{l}\text { 2. Does the exhibition support patron } \\
\text { interactions that contribute to information transfer } \\
\text { and retention, and make the quality of virtually }\end{array}$ & Not applicable \\
\hline
\end{tabular}




\begin{tabular}{|c|c|}
\hline $\begin{array}{l}\text { presented information meet or exceed a real life } \\
\text { experience? (Milekic:2007) }\end{array}$ & \\
\hline $\begin{array}{l}\text { 3. How can the exhibition be assessed in } \\
\text { terms of Kalfatovic's five types of online exhibition: } \\
\text { is it aesthetic, emotive, evocative, didactic or } \\
\text { entertaining, or a composite of several of these } \\
\text { definitions? }\end{array}$ & $\begin{array}{l}\text { Does not really fulfil any of the five criteria- just a } \\
\text { brief summary of the exhibition and a link to the } \\
\text { Exhibition poster. Didactic to a small degree }\end{array}$ \\
\hline $\begin{array}{l}4 . \quad \text { Is the exhibition maintained and actively } \\
\text { managed to ensure all links are accessible to } \\
\text { patrons? }\end{array}$ & $\begin{array}{l}\text { Link to exhibition poster functions fine, all other } \\
\text { links and search boxes on left hand side lead } \\
\text { nowhere. Links at top of page elicit } 404 \text {-not found } \\
\text { errors. } \\
\text { Slightly warped image of University of Otago coat } \\
\text { of arms leads to University main page, five of seven } \\
\text { links at bottom do not function ( } 404 \text { error) }\end{array}$ \\
\hline $\begin{array}{l}5 . \quad \text { Is the design such that it is easy to navigate } \\
\text { and does not contain too much or too sparse a } \\
\text { range of artefacts per page? }\end{array}$ & $\begin{array}{l}\text { A brief summary on the page and a link to the } \\
\text { exhibition poster is the extent of the exhibition. } \\
\text { Certainly too sparse regarding both text and image. }\end{array}$ \\
\hline $\begin{array}{l}\text { Is the exhibition accessible to persons with } \\
\text { disabilities, including adaptive technology? }\end{array}$ & Not applicable \\
\hline $\begin{array}{l}7 . \quad \text { Does the exhibition provide usage data and } \\
\text { other data to assess standardization and } \\
\text { usefulness? }\end{array}$ & $\begin{array}{l}\text { Not applicable (see Portrait of a Gentleman Scholar: } \\
\text { celebrating the life and legacy of Esmond de Beer) }\end{array}$ \\
\hline $\begin{array}{l}\text { 8. How does the exhibition reflect local and } \\
\text { national culture, and the purpose of the special } \\
\text { collections? }\end{array}$ & Not applicable \\
\hline
\end{tabular}

\section{ALL ABOARD! The Ernie Webber Railway Collection}

1. Has a balance of formalist and analyst methodology been achieved? (Lester:2006)

Yes- a visually appealing exhibition utilising vibrant blue on the left and right edges which compliments the images and text at the centre. The exhibition design flows well and is consistent. 


\begin{tabular}{|c|c|}
\hline $\begin{array}{l}2 . \quad \text { Does the exhibition support patron } \\
\text { interactions that contribute to information transfer } \\
\text { and retention, and make the quality of virtually } \\
\text { presented information meet or exceed a real life } \\
\text { experience? (Milekic:2007) }\end{array}$ & $\begin{array}{l}\text { Yes- this is one of the best exhibitons analysed in } \\
\text { terms of meeting or exceeding real life experience. } \\
\text { The lvel of detail is thorough yet the patron, much } \\
\text { like the Walt Whitman's Leave of Grass exhibition } \\
\text { can navigate from cabinet to cabinet at their own } \\
\text { pace. Niether text nor images jar the experience. }\end{array}$ \\
\hline $\begin{array}{l}\text { 3. How can the exhibition be assessed in } \\
\text { terms of Kalfatovic's five types of online exhibition: } \\
\text { is it aesthetic, emotive, evocative, didactic or } \\
\text { entertaining, or a composite of several of these } \\
\text { definitions? }\end{array}$ & $\begin{array}{l}\text { Aesthetic, evocative, didactic and entertaining, this } \\
\text { overview of Ernie Webbers life and collection is } \\
\text { visually appealing and intellectually stimulating. }\end{array}$ \\
\hline $\begin{array}{l}4 . \quad \text { Is the exhibition maintained and actively } \\
\text { managed to ensure all links are accessible to } \\
\text { patrons? }\end{array}$ & $\begin{array}{l}\text { All links function perfectly, no external links } \\
\text { utilised. }\end{array}$ \\
\hline $\begin{array}{l}5 . \quad \text { Is the design such that it is easy to navigate } \\
\text { and does not contain too much or too sparse a } \\
\text { range of artefacts per page? }\end{array}$ & $\begin{array}{l}\text { Yes, ease of navigation and well balanced between } \\
\text { image and text throughout. }\end{array}$ \\
\hline $\begin{array}{l}\text { 6. Is the exhibition accessible to persons with } \\
\text { disabilities, including adaptive technology? }\end{array}$ & $\begin{array}{l}\text { The size of the font is good, and the use of colour is } \\
\text { vibrant but does not affect legibility of font or } \\
\text { headings. }\end{array}$ \\
\hline $\begin{array}{l}\text { 7. Does the exhibition provide usage data and } \\
\text { other data to assess standardization and } \\
\text { usefulness? }\end{array}$ & $\begin{array}{l}\text { Not applicable (see Portrait of a Gentleman Scholar: } \\
\text { celebrating the life and legacy of Esmond de Beer) }\end{array}$ \\
\hline $\begin{array}{l}\text { 8. How does the exhibition reflect local and } \\
\text { national culture, and the purpose of the special } \\
\text { collections? }\end{array}$ & $\begin{array}{l}\text { The exhibitions reflects local and national culture } \\
\text { by evoking a sense of the passion that Webber had } \\
\text { for travel and for railways. }\end{array}$ \\
\hline
\end{tabular}




\begin{tabular}{|c|c|}
\hline $\begin{array}{l}\text { 1. Has a balance of formalist and analyst } \\
\text { methodology been achieved? (Lester:2006) }\end{array}$ & $\begin{array}{l}\text { Yes- this exhibition has the most successful } \\
\text { execution of a balance between formalist and } \\
\text { analyst of all surveyed. The black background } \\
\text { makes the vibrant book covers stand out, and the } \\
\text { introduction is split which aids in balancing the } \\
\text { analyst aspect. }\end{array}$ \\
\hline $\begin{array}{l}2 . \quad \text { Does the exhibition support patron } \\
\text { interactions that contribute to information transfer } \\
\text { and retention, and make the quality of virtually } \\
\text { presented information meet or exceed a real life } \\
\text { experience? (Milekic:2007) }\end{array}$ & $\begin{array}{l}\text { Very effectively- The online exhibition recreates } \\
\text { the physical one while allowing patrons a closer } \\
\text { look at all book covers in high resolution. }\end{array}$ \\
\hline $\begin{array}{l}\text { 3. How can the exhibition be assessed in } \\
\text { terms of Kalfatovic's five types of online exhibition: } \\
\text { is it aesthetic, emotive, evocative, didactic or } \\
\text { entertaining, or a composite of several of these } \\
\text { definitions? }\end{array}$ & $\begin{array}{l}\text { Has a good balance of all five of these criteria. } \\
\text { Appealing to look at, entertaining subject matter, } \\
\text { informative and evocative, given the sometimes } \\
\text { controversial cover art and fiction subjects }\end{array}$ \\
\hline $\begin{array}{l}\text { 4. Is the exhibition maintained and actively } \\
\text { managed to ensure all links are accessible to } \\
\text { patrons? }\end{array}$ & $\begin{array}{l}\text { All links function perfectly, no external links } \\
\text { utilised. }\end{array}$ \\
\hline $\begin{array}{l}5 . \quad \text { Is the design such that it is easy to navigate } \\
\text { and does not contain too much or too sparse a } \\
\text { range of artefacts per page? }\end{array}$ & $\begin{array}{l}\text { A good balance of information on the main page- } \\
\text { each cabinet and its artefacts can be perused in } \\
\text { order via 'previous' and 'next' buttons, and one can } \\
\text { always return to the main page via a large 'home' } \\
\text { button which is consistent throughout all artefacts } \\
\text { and cabinets. }\end{array}$ \\
\hline $\begin{array}{l}\text { 6. Is the exhibition accessible to persons with } \\
\text { disabilities, including adaptive technology? }\end{array}$ & $\begin{array}{l}\text { The font is an appropriate size, and the use of } \\
\text { colour is such that all images have hover functions } \\
\text { detailing what the cabinet contains, allowing for } \\
\text { vision impaired users. }\end{array}$ \\
\hline
\end{tabular}




\begin{tabular}{|l|l|}
\hline $\begin{array}{l}\text { 7. Does the exhibition provide usage data and } \\
\text { other data to assess standardization and } \\
\text { usefulness? }\end{array}$ & $\begin{array}{l}\text { Not applicable (see Portrait of a Gentleman Scholar: } \\
\text { celebrating the life and legacy of Esmond de Beer) }\end{array}$ \\
\hline $\begin{array}{l}\text { 8. How does the exhibition reflect local and } \\
\text { national culture, and the purpose of the special } \\
\text { collections? }\end{array}$ & $\begin{array}{l}\text { The exhibition reflects once again the collaborative } \\
\text { nature of Special Collections, in that is conveys a } \\
\text { wide variety of pulp fiction covers while situating } \\
\text { them in their local, antipodean and international } \\
\text { contexts. }\end{array}$ \\
\hline
\end{tabular}

\section{From Pigskin to Paper: The Art and Craft of Bookbinding}

\begin{tabular}{|l|l|}
\hline $\begin{array}{l}1 . \quad \text { Has a balance of formalist and analyst } \\
\text { methodology been achieved? (Lester:2006) }\end{array}$ & $\begin{array}{l}\text { Yes- the design is similar to that of 'Pulp Fiction', } \\
\text { using a dark background, reflecting the exhibition } \\
\text { poster font in the heading and containing clickable } \\
\text { images which open and reveal further detail. }\end{array}$ \\
\hline $\begin{array}{l}\text { 2. Does the exhibition support patron } \\
\text { interactions that contribute to information transfer } \\
\text { and retention, and make the quality of virtually } \\
\text { presented information meet or exceed a real life } \\
\text { experience? (Milekic:2007) }\end{array}$ & Yes (refer to Pulp Fiction) \\
\hline $\begin{array}{l}\text { 3. How can the exhibition be assessed in } \\
\text { terms of Kalfatovic's five types of online exhibition: } \\
\text { is it aesthetic, emotive, evocative, didactic or } \\
\text { entertaining, or a composite of several of these } \\
\text { definitions? }\end{array}$ & $\begin{array}{l}\text { Aesthetic- very visually appealing with great detail } \\
\text { which are evocative and didactic. }\end{array}$ \\
\hline $\begin{array}{l}\text { Is the exhibition maintained and actively } \\
\text { managed to ensure all links are accessible to } \\
\text { patrons? }\end{array}$ & $\begin{array}{l}\text { All links function perfectly, no external links } \\
\text { utilised. }\end{array}$ \\
\hline $\begin{array}{l}\text { Is the design such that it is easy to navigate } \\
\text { and does not contain too much or too sparse a } \\
\text { range of artefacts per page? }\end{array}$ & $\begin{array}{l}\text { There is a high volume of images, which are } \\
\text { appealing but take some time to load. Individual } \\
\text { artefacts are displayed well and patrons can } \\
\text { navigate home or 'next' from within the enlarged } \\
\text { image }\end{array}$ \\
\hline
\end{tabular}




\begin{tabular}{|c|c|}
\hline $\begin{array}{l}\text { 6. Is the exhibition accessible to persons with } \\
\text { disabilities, including adaptive technology? }\end{array}$ & $\begin{array}{l}\text { Yes, however the fine font describing each cabinet } \\
\text { artefact could be darker to enhance accessibility. }\end{array}$ \\
\hline $\begin{array}{l}7 . \quad \text { Does the exhibition provide usage data and } \\
\text { other data to assess standardization and } \\
\text { usefulness? }\end{array}$ & $\begin{array}{l}\text { Not applicable (see Portrait of a Gentleman Scholar: } \\
\text { celebrating the life and legacy of Esmond de Beer) }\end{array}$ \\
\hline $\begin{array}{l}\text { 8. How does the exhibition reflect local and } \\
\text { national culture, and the purpose of the special } \\
\text { collections? }\end{array}$ & $\begin{array}{l}\text { The exhibition reflects the purpose of Special } \\
\text { Collections, showing in exquisite detail book } \\
\text { bindings and covers spanning several hundred } \\
\text { years }\end{array}$ \\
\hline
\end{tabular}




\section{Appendix III}

a) A screenshot of the University of Otago web-site accessibility page, indicating key and browser short cuts.

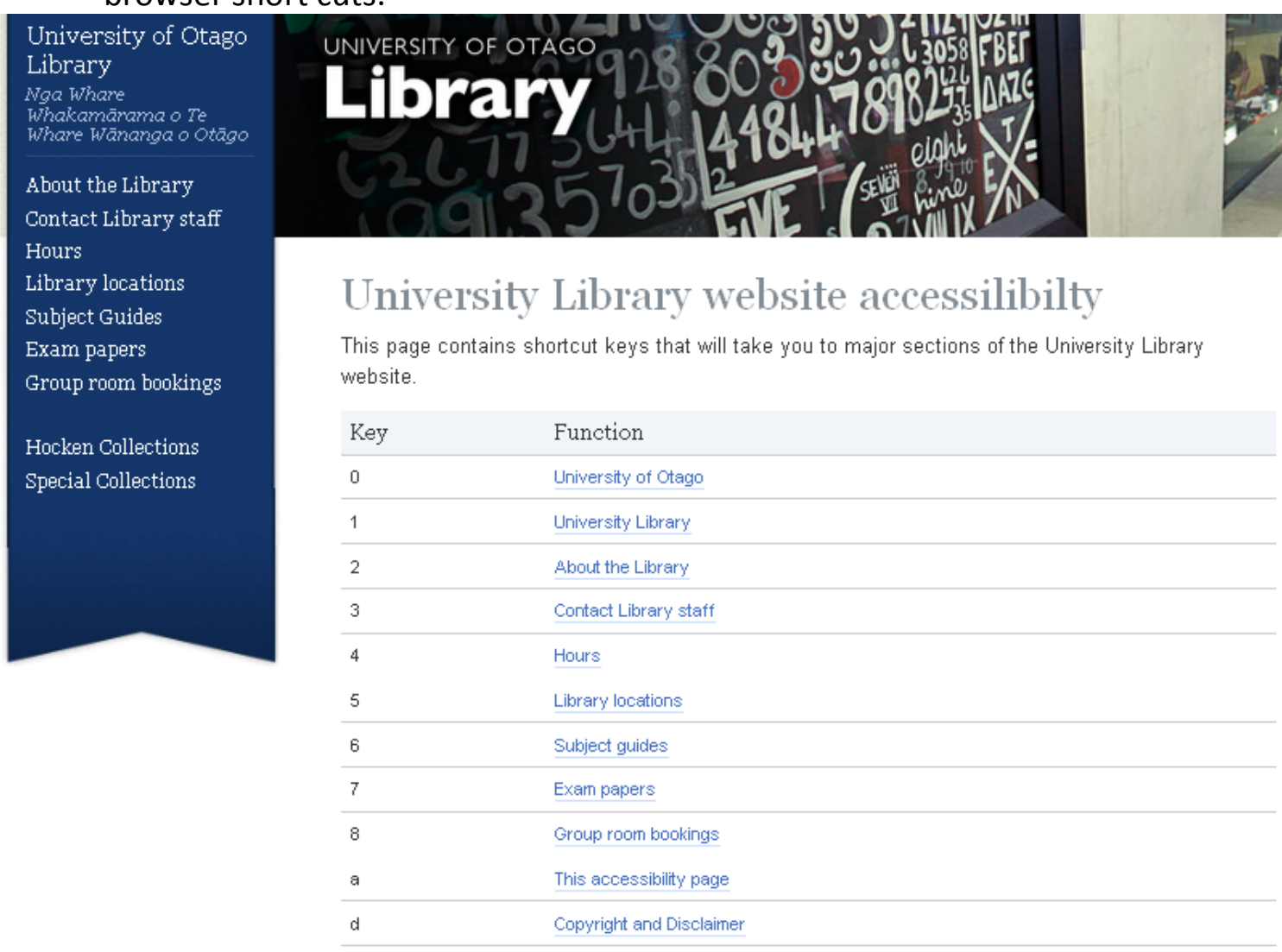

Browser Shortcuts

The following table outlines modern browsers and the key combinations required.

\begin{tabular}{lll} 
Browser & Windows & Mac \\
$\begin{array}{l}\text { Internet Explorer } \\
6+\end{array}$ & Alt+accesskey & \\
\hline Safari 4+ & Alt+accesskey (then hit Enter) & Ctrl+Option+accesskey \\
\hline Firefox 14+ & Shift+A.lt+accesskey & Ctrl+Option+accesskey \\
\hline Google Chrome 3+ & Alt+accesskey & Ctrl+Option+accesskey \\
\hline Opera 8+ & $\begin{array}{l}\text { Shift+Esc (then choose accesskey from the } \\
\text { list) }\end{array}$ & $\begin{array}{l}\text { Shift+Esc (then choose accesskey from the } \\
\text { list) }\end{array}$
\end{tabular}

In most other web browsers, the user invokes the access key by pressing Alt (on PC) or Ctrl (on Mac) simultaneously with the appropriate accesskey character on the keyboard. Some browsers (for example Internet Explorer on Windows) then require you to hit the enter key.

\section{Appendix IV}




\section{Screenshots of ten exhibitions}

Note: due to the variation between screen formats, some of the exhibitions are displayed in landscape page layout.

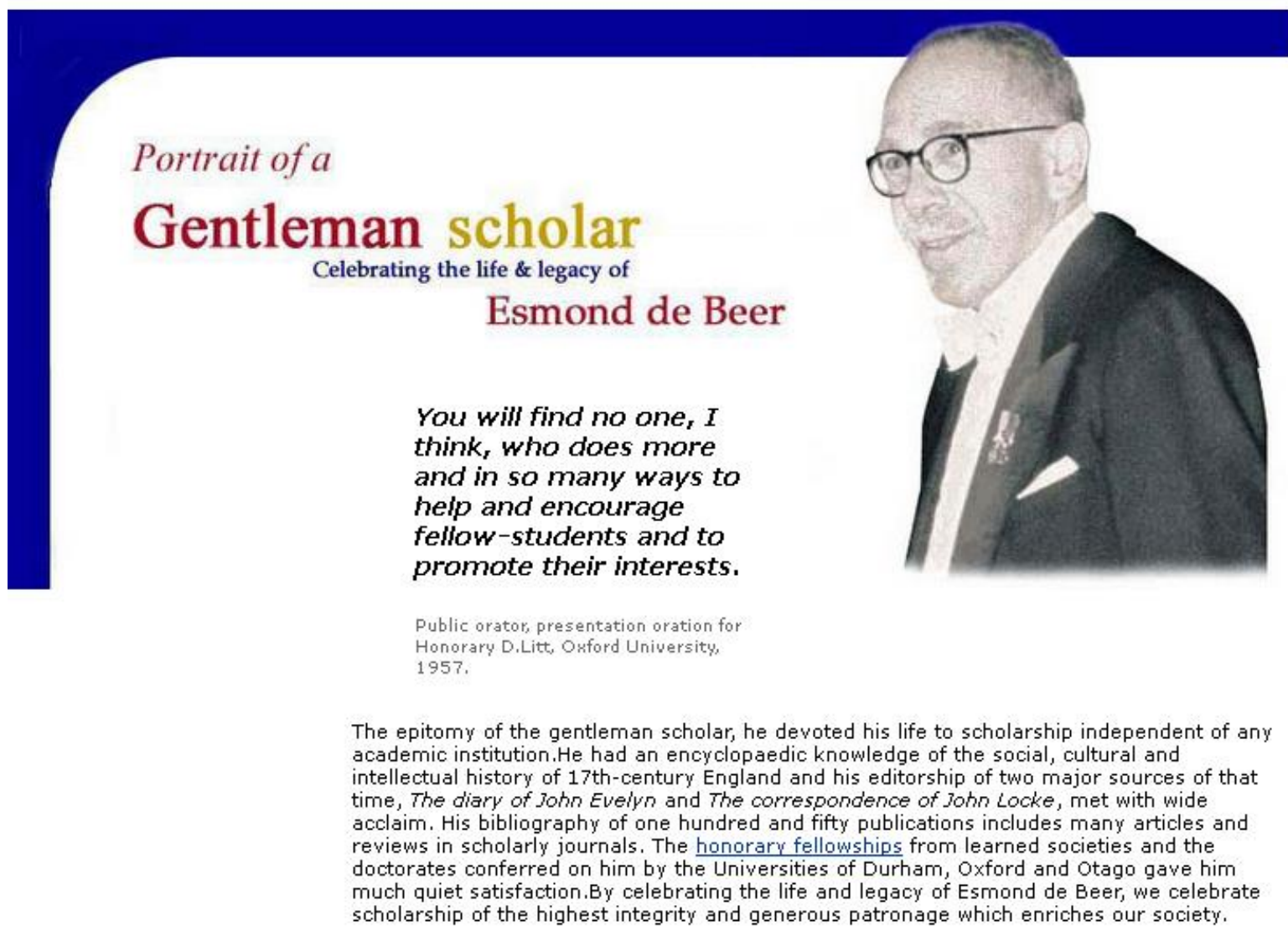
21 March - 13 June $2002 \sim$ de Beer Gallery Central Library, University of Otago Monday - Friday 8:30 am - 5:00 pm Contact Special Collections



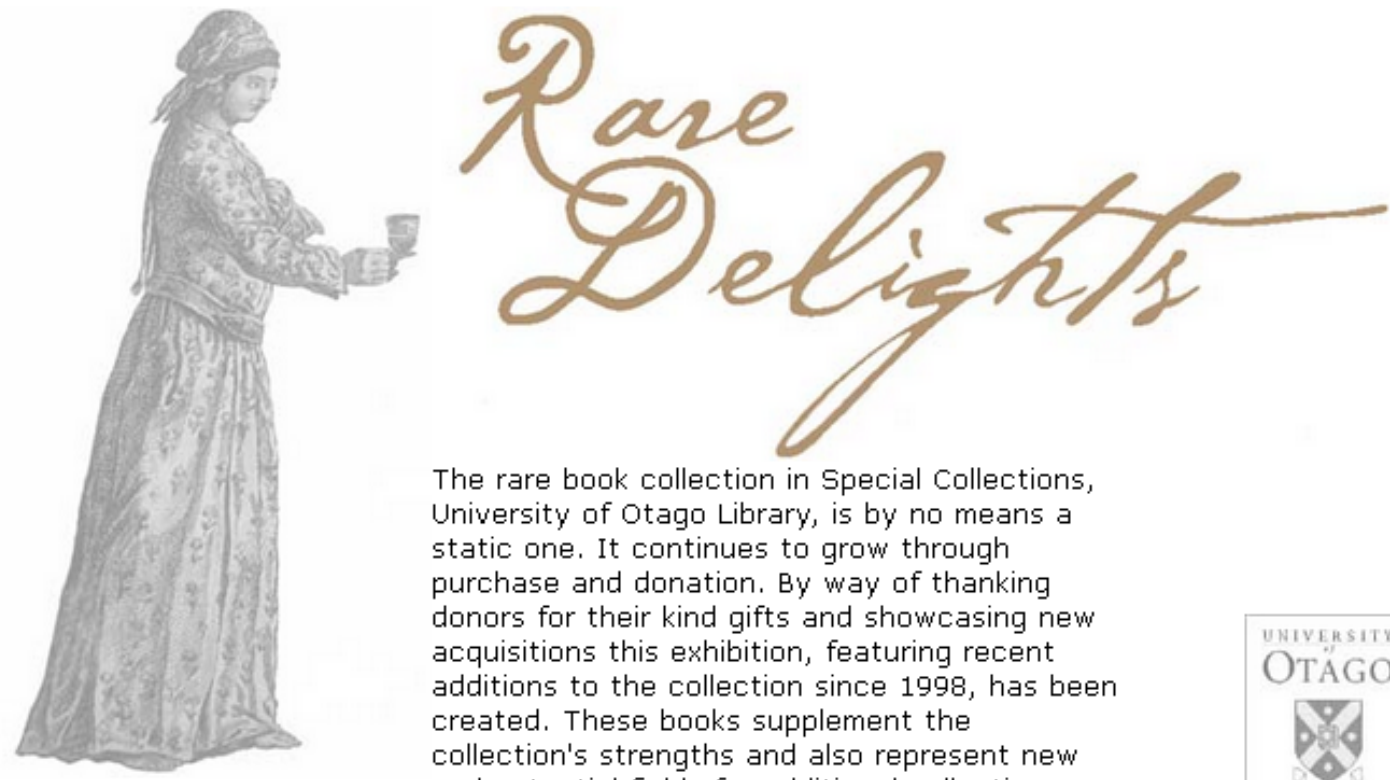

The rare book collection in Special Collections, University of Otago Library, is by no means a static one. It continues to grow through purchase and donation. By way of thanking donors for their kind gifts and showcasing new acquisitions this exhibition, featuring recent additions to the collection since 1998, has been created. These books supplement the collection's strengths and also represent new and potential fields for additional collecting.

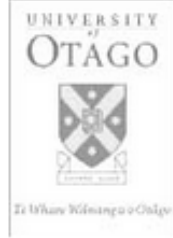

13 December 2002 - 13 March $2003 \sim$ de Beer Gallery Central Library, University of Otagc Monday - Friday $8: 30 \mathrm{am}-5: 00 \mathrm{pm}$ Contact the curator

15 January, 2003

Enter $\cdot 2$

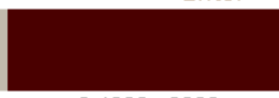

(9) $1998 \cdot 2003$

University of Otago Librany

$<$ 


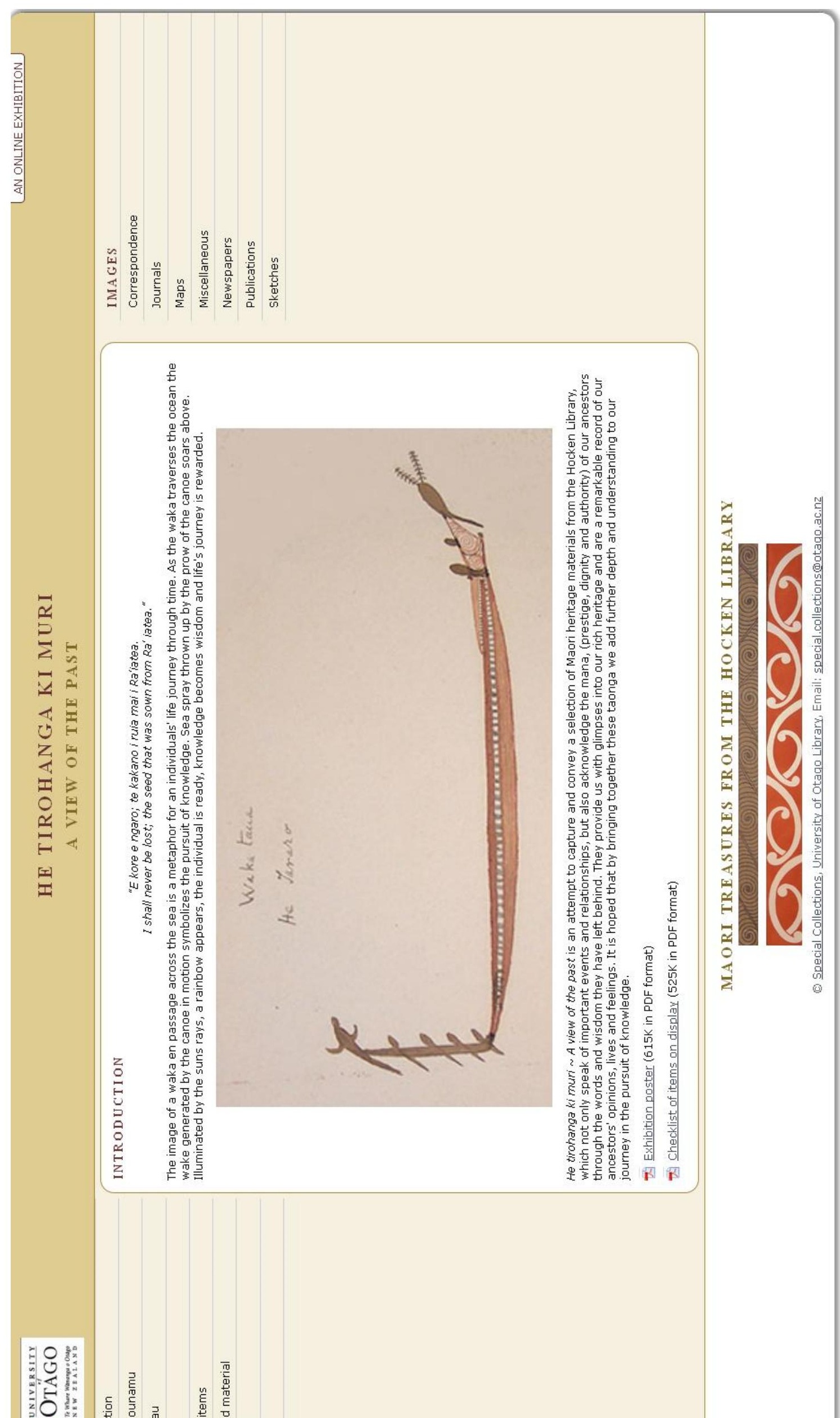




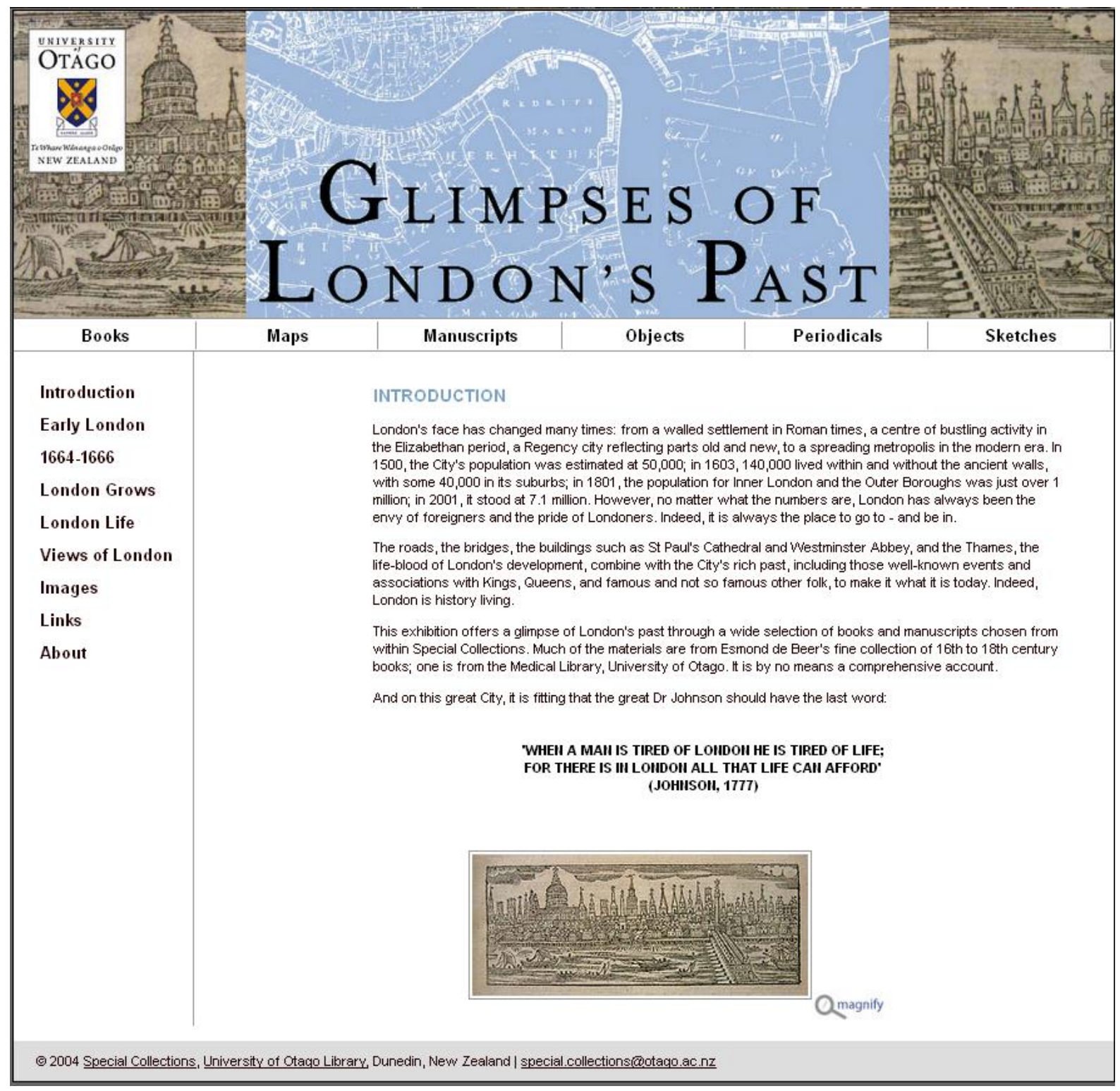




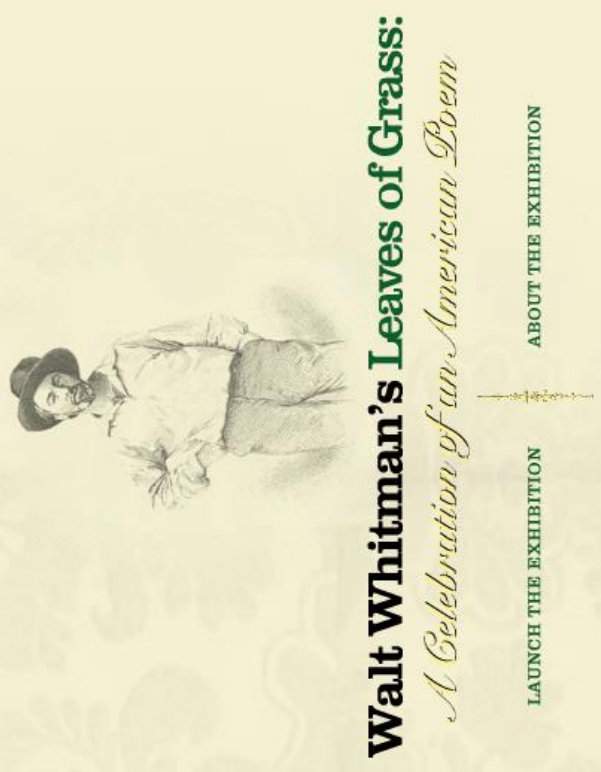




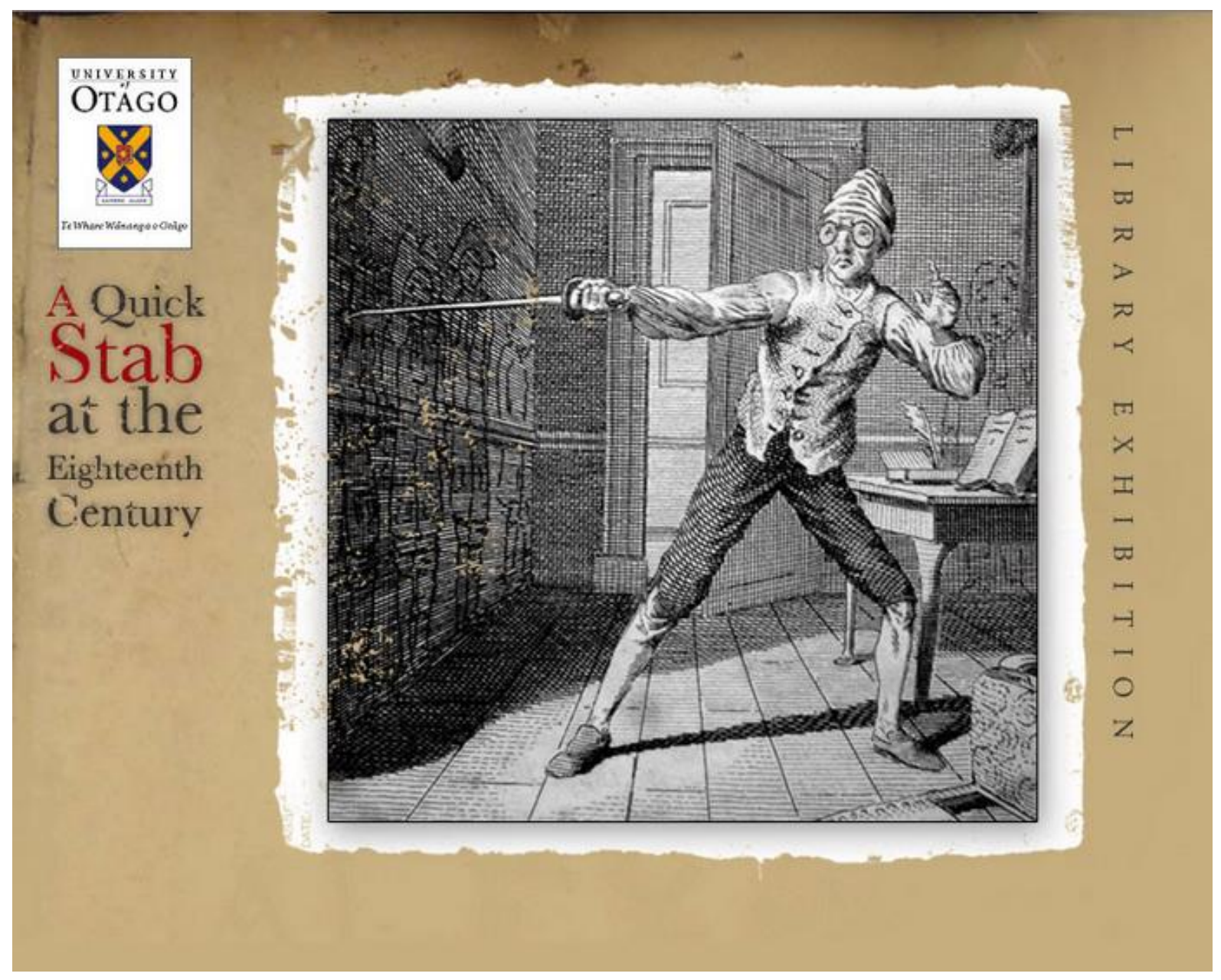




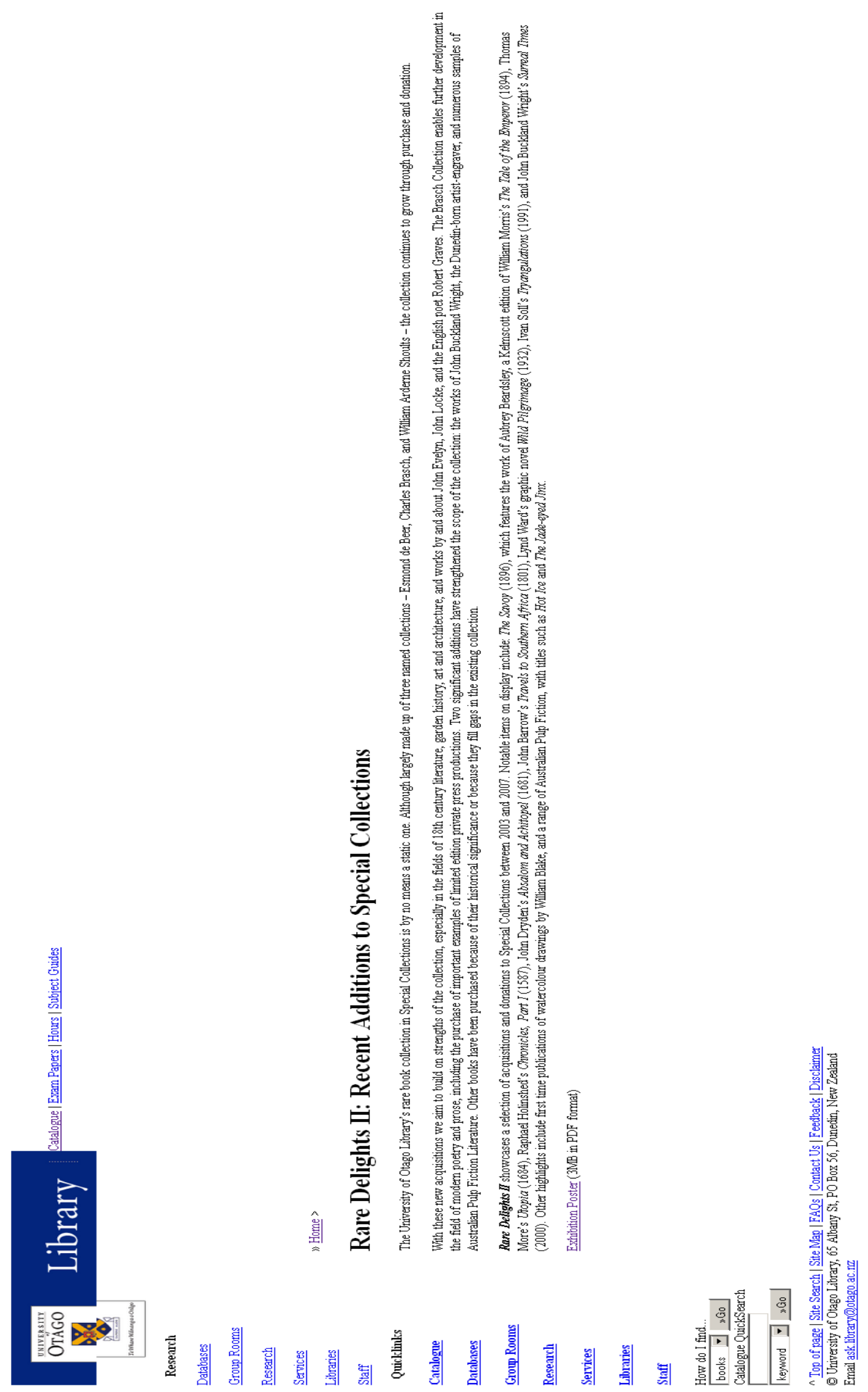




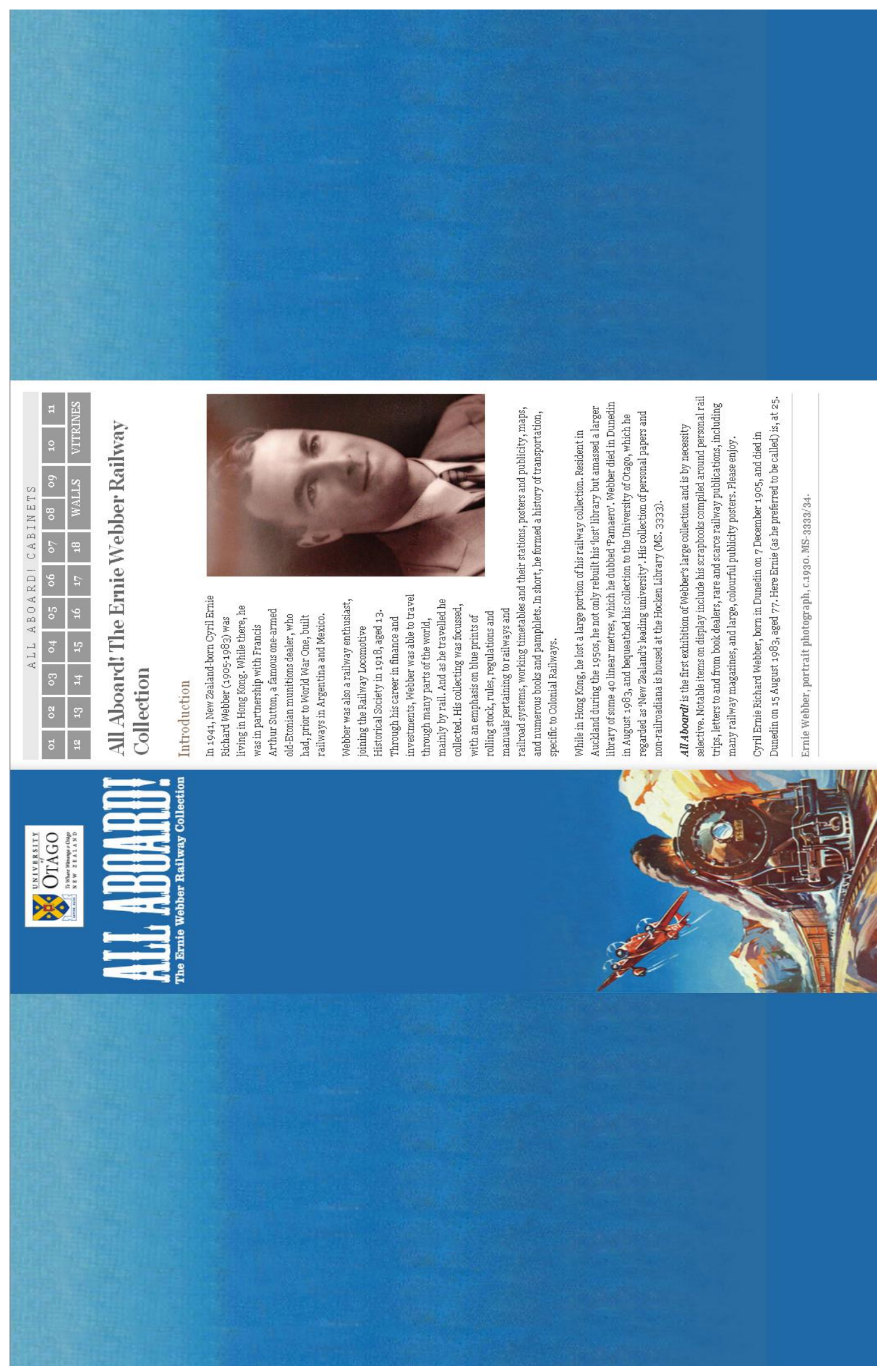




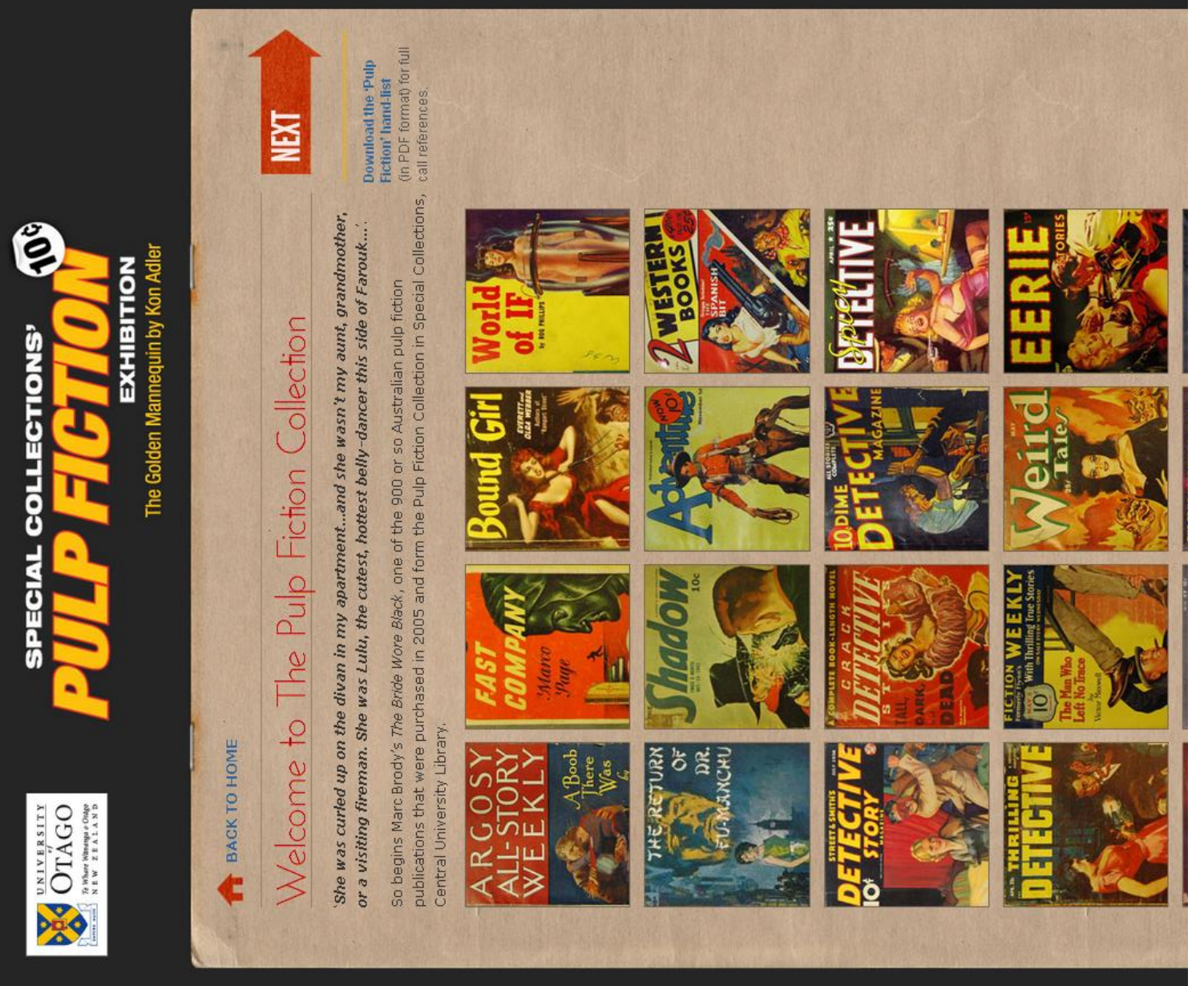




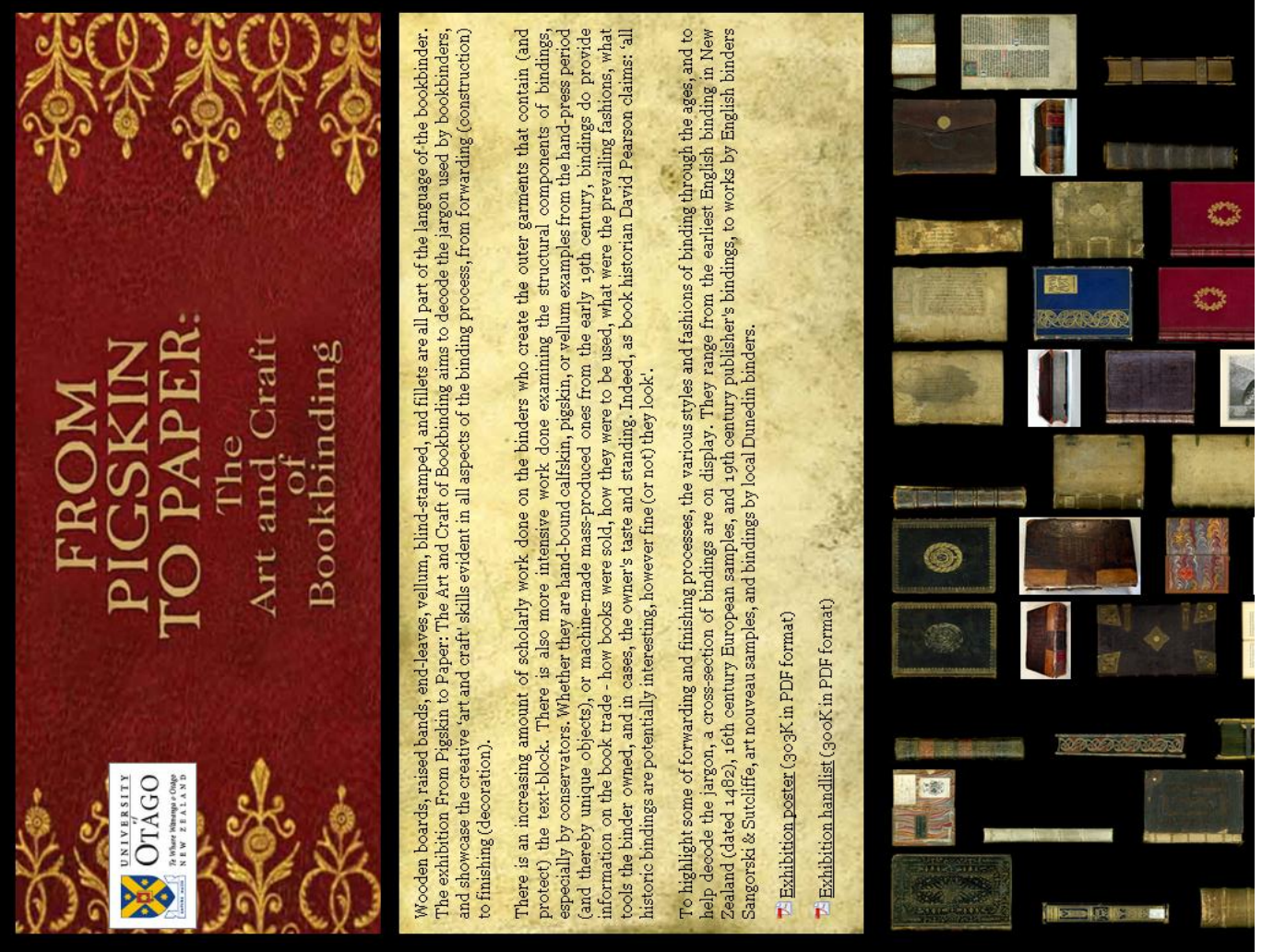

